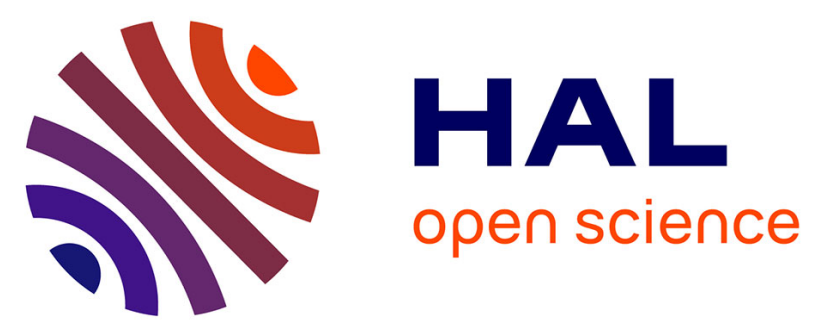

\title{
A new global database of $\delta 98$ Mo in molybdenites: A literature review and new data A new global database of $\delta 98$ Mo in molybdenites: a literature review and new data
}

\author{
Noémie Breillat, Catherine Guerrot, Eric Marcoux, Philippe Négrel
}

\section{To cite this version:}

Noémie Breillat, Catherine Guerrot, Eric Marcoux, Philippe Négrel. A new global database of $\delta$ 98 Mo in molybdenites: A literature review and new data A new global database of $\delta 98$ Mo in molybdenites: a literature review and new data. Journal of Geochemical Exploration, 2016, 161, pp.1-15. 10.1016/j.gexplo.2015.07.019 . insu-01196585

\section{HAL Id: insu-01196585 \\ https://hal-insu.archives-ouvertes.fr/insu-01196585}

Submitted on 10 Sep 2015

HAL is a multi-disciplinary open access archive for the deposit and dissemination of scientific research documents, whether they are published or not. The documents may come from teaching and research institutions in France or abroad, or from public or private research centers.
L'archive ouverte pluridisciplinaire HAL, est destinée au dépôt et à la diffusion de documents scientifiques de niveau recherche, publiés ou non, émanant des établissements d'enseignement et de recherche français ou étrangers, des laboratoires publics ou privés. 


\section{Accepted Manuscript}

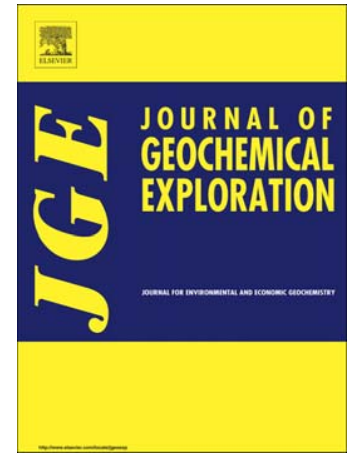

PII:

S0375-6742(15)30044-3

Reference:

10.1016/j.gexplo.2015.07.019

To appear in: Journal of Geochemical Exploration

Received date: 1 August 2014

Revised date: $\quad 30$ June 2015

Accepted date: $\quad 31$ July 2015

Please cite this article as: Breillat, N., Guerrot, C., Marcoux, E., Négrel, Ph., A new global database of $\delta^{98} \mathrm{Mo}$ in molybdenites: A literature review and new data, Journal of Geochemical Exploration (2015), doi: 10.1016/j.gexplo.2015.07.019

This is a PDF file of an unedited manuscript that has been accepted for publication. As a service to our customers we are providing this early version of the manuscript. The manuscript will undergo copyediting, typesetting, and review of the resulting proof before it is published in its final form. Please note that during the production process errors may be discovered which could affect the content, and all legal disclaimers that apply to the journal pertain. 


\title{
A new global database of $\delta^{98} \mathrm{Mo}$ in molybdenites:
}

\section{a literature review and new data}

\author{
N. Breillat, ${ }^{a, b, c,}$ C. Guerrot ${ }^{\text {a, b, c, E. Marcoux }}{ }^{c}$ Ph. Négrel ${ }^{\text {a, b, c, }}$
}

a - BRGM, ISTO, UMR 7327, BP 36009, 45060 Orléans, France

b - CNRS/INSU, ISTO, UMR 7327, 45071 Orléans, France

c - University of Orléans, ISTO, UMR 7327, 45071, Orléans, France

Corresponding author:

Noémie Breillat

BRGM - LAB/ISO

3 avenue Claude Guillemin BP 6009

45060 Orléans cedex 2 - France

Phone: +33 (0)2 38643648

E-mail: noemie.breillat@gmail.com

\begin{abstract}
Isotopic compositions of $\mathrm{Mo}$ in molybdenites were used for deciphering a possible genetic link between isotopic variations and mineralizing processes, based on a worldwide molybdenite databank. We compared the $\delta^{98 / 95} \mathrm{Mo}$ (hereafter referred as $\delta^{98} \mathrm{Mo}_{\text {NIST }}$ ) of 391 molybdenite samples (193 from the literature, 198 for this study) from different localities, different types of occurrences and different ages. The 198 molybdenite samples we analysed represent various types of mineralization in 6 granites, 11 pegmatites, 6 perigranitic veins, 2 greisen, 28 porphyry deposits, 5 skarns, 1 IOCG, and 9 Alpine-type fissure veins, with ages varying from $5 \mathrm{Ma}$ to $2.7 \mathrm{Ga}$. The Mo isotopic composition was determined with an MC-ICP-MS Neptune after aqua regia dissolution and adjustment to $[\mathrm{Mo}]=1 \mu \mathrm{g} \cdot \mathrm{ml}^{-1}$. Mass bias was corrected by using $\mathrm{Zr}$ as dopant and standard-samplestandard bracketing. The $\delta^{98} \mathrm{Mo}_{\text {NIST }}$ ratios were normalized to NIST3134. External reproducibility is $0.07 \%$ o $(2 \sigma)$. The overall range of the $\delta^{98} \mathrm{Mo}_{\text {NIST }}$ ratio in the 391 molybdenite samples varied from 1.62 to $2.27 \%$, being higher for molybdenite formed in Alpine-type veins, greisen, perigranitic veins and IOCG, than for that in granite, pegmatite, porphyry deposits and skarns. The crystallization temperature can explain some of these differences, as polymetallic Alpine-type fissure veins broadly crystallize at lower temperatures than granite, pegmatite and porphyry deposits. For some
\end{abstract}


occurrences the $\delta^{98} \mathrm{Mo}_{\text {NIST }}$ was determined on several molybdenite samples, showing variability at occurrence scale. For example, in the Azegour skarn (Morocco) the $\delta^{98} \mathrm{Mo}_{\mathrm{NIST}}$ varies from -0.60 to $0.42 \%$ ( $n=29)$, and in "Ravin de la Ruine" Alpine-type fissure veins (France) the variation is from -0.08 to $0.77 \%$ o $(n=3)$. No correlation is seen between $\delta^{98} \mathrm{Mo}_{\text {NIST }}$ and the age of the deposits.

Keywords: molybdenum, molybdenite, isotopes, mineralization

\section{Introduction}

Over the past decades, the use of Mo-isotope compositions in the Earth Sciences has strongly increased, as well as that of other transition metals such as Fe, Cu, and $\mathrm{Zn}$ (Zhu et al., 2002). Moisotope applications were mainly developed for reconstructing paleo-redox conditions in oceans (Barling et al., 2001; Siebert et al., 2003; Arnold et al., 2004), and for investigating the main Mo input into oceans from weathering (Archer and Vance, 2008). More recently, Mo and other transitionmetal isotopes were used for studying trace-metal pollution (Cu-Zn isotopes: Markl et al., 2006; Borrok et al., 2008; Mathur et al. 2013; Mo isotopes: Neubert et al., 2011; Chappaz et al., 2012; Lane et al., 2013). Molybdenum is used for alloying steel to increase strength and temperature resistance and for tinting. As molybdenite $\left(\mathrm{MoS}_{2}\right)$ is presently the only mineral source of $\mathrm{Mo}$, it is important to study $\mathrm{MoS}_{2}$ mineralizing processes.

Several studies have reported the Mo-isotope composition of ore deposits, particularly in order to constrain mineralizing processes (Hannah et al., 2007; Mathur et al., 2010; Greber et al., 2011; 2014; Shafiei et al., 2014). Understanding Mo-isotope fractionation processes during ore-deposit genesis is very important for understanding the mineralizing process as a whole. However, data normalization is problematic as each laboratory uses its own in-house standards, rendering inter-laboratory comparison of data sets difficult. Here, we used the NIST3134, recently proposed as the international SMo standard (Wen et al., 2010; Greber et al., 2012; Goldberg et al., 2013; Nägler et al., 2013) for homogenizing data sets of Mo isotopes in molybdenites, thus allowing the comparison of more than 391 data sets. 
We discuss Mo-isotope ratios of 391 molybdenite samples from ore deposits all over the world and, for most samples, with a well understood geological context. The purpose of this study was twofold: (1) To investigate the isotopic variability of molybdenites from various geological settings covering a large time scale from Archean to "Recent" ( $<2 \mathrm{Ma})$; and (2) To investigate potential relationships between Mo-isotope variations and mineralizing processes. It is worth noting that samples from large Mo deposits, including Bugdaya (Kovalenker et al., 2011) and Zhireken (Berzina and Sotnikov, 2010) in Russia, Climax in the United States (Geraghty et al., 1988) and Chuquicamata in Chile (Ballard et al., 2001), or from newly discovered ones like Hashitu in China (Zhai et al., 2014) were analysed as part of this study. None of these major sites, of prime importance in terms of molybdenum reserves, have been analysed for molybdenum isotopic compositions.

\section{The samples used for the databank}

Deciphering the possible variations of Mo-isotope ratios in molybdenites, according to deposit type, geological context and age setting, requires the largest possible database. Thus, for this study we analysed 198 molybdenites for Mo isotopes, and, to complete our data set, we added all data from Barling et al. (2001), Siebert et al. (2001), Wieser and de Laeter (2003), Malinovsky et al. (2005, 2007), Hannah et al. (2007), Mathur et al. (2010), Greber et al. (2011, 2014), and Shafiei et al. (2014). These literature data used various different normalization standards and thus, to allow comparison, they were recalculated according to NIST3134 thanks to intercalibrations performed by Malinovsky et al. (2007), Golderberg et al. (2013) and Lane et al. (2013). The database now contains 391 data sets, including 193 molybdenite samples from the literature and 198 from our work. The samples have a world-wide provenance (Fig. 1); they were collected from ore deposits or came from various occurrences where the molybdenite content is not of economic interest. The types of molybdenite occurrences/deposits as well as studied sites and samples are described in Table 1.

\section{Method}


The first reliable isotope measurements for Mo were done by thermal-ionization mass spectrometry (TIMS) in the 1960s (Murthy, 1963) and improved regularly (Wieser and De Laeter, 2000) up to the development of the MC-ICP-MS method (Malinovsky et al., 2005). Molybdenite (molybdenum sulphide, $\mathrm{MoS}_{2}$ ) is the main molybdenum ore. As Mo is the major cation in molybdenite (59.94\%), there is no need for chemical purification and/or concentration prior to analysis (Barling et al., 2001).

Greber et al. (2011) found isotope variations within a single sample of molybdenite. Therefore, in order to obtain a representative value of the sample, the largest possible amount of molybdenite was handpicked and then powdered in order to homogenize the sample. Around $10 \mathrm{mg}$ of molybdenite powder were dissolved in $4 \mathrm{ml}$ of aqua regia $\left(1 \mathrm{ml}\right.$ of $\mathrm{HNO}_{3} 7 \mathrm{~N}$ and $3 \mathrm{ml}$ of $\mathrm{HCl} 8 \mathrm{~N}$ ) at $100{ }^{\circ} \mathrm{C}$ in PTFE beakers until complete dissolution. The solutions were dried and the residues were dissolved in $10 \mathrm{ml}$ of $\mathrm{HNO}_{3} 3 \%(\mathrm{v} / \mathrm{v})$. From this concentrated solution, a final solution was prepared in $\mathrm{HNO}_{3} 3 \%$ in order to get a final Mo concentration of $1 \mu \mathrm{g} \cdot \mathrm{ml}^{-1} . \mathrm{Zr}$ was added to this solution with a concentration of $0.5 \mu \mathrm{g} \cdot \mathrm{ml}^{-1}$. The Mo blank level for the whole procedure was less than $1 \%$ and thus negligible as compared to the sample concentration.

Mo-isotopic measurements were done with an MC-ICP-MS Neptune (Thermo-Finnigan) at BRGM (Orléans, France), the experimental conditions being given in supplementary data. The MC-ICP-MS is preferred over TIMS for Mo-isotope studies since Lee and Halliday (1995) showed that the MC-ICPMS instrument could produce precise and reproducible isotopic data for elements like Mo, that are difficult to ionize and measure with TIMS. The Neptune is a double-focusing mass spectrometer equipped with eight adjustable Faraday cups and one fixed axial cup, and skimmer cones $\mathrm{H}$ were used during this work. Zirconium $(\mathrm{Zr})$ and ruthenium $(\mathrm{Ru})$ produce several isobaric interferences on 92, 94, 96 and 96, 98, 100 masses, and only ${ }^{95} \mathrm{Mo}$ and ${ }^{97} \mathrm{Mo}$ are free of interference. Such interference is easily corrected with the following cup configuration: ${ }^{90} \mathrm{Zr}-\mathrm{L} 3,{ }^{91} \mathrm{Zr}-\mathrm{L} 2,{ }^{92} \mathrm{Mo}-{ }^{92} \mathrm{Zr}-\mathrm{L} 1$, ${ }^{94} \mathrm{Mo}-{ }^{94} \mathrm{Zr}-\mathrm{Ax},{ }^{95} \mathrm{Mo}-\mathrm{H} 1,{ }^{97} \mathrm{Mo}-\mathrm{H} 2,{ }^{98} \mathrm{Mo}-{ }^{98} \mathrm{Ru}-\mathrm{H} 3,{ }^{99} \mathrm{Ru}-\mathrm{H} 4$. In our samples and standards, ruthenium has never been detected. Mo-isotope measurements were run within sequences composed by blank, standard and sample analyses. After the sample and standard analyses, two minutes of washing 
$\left(\mathrm{HNO}_{3} 3 \%\right)$ allowed obtaining correct blanks. The reported data represent the mean value of a minimum of 5 runs of 20 measurements.

Mass bias was corrected by ${ }^{90 / 91} \mathrm{Zr}$ external spiking (Zirconium ICP standard CertiPUR Merck) at $0.5 \mu \mathrm{g} \cdot \mathrm{ml}^{-1}$ (Anbar et al., 2001) and standard-sample-standard bracketing. The external reproducibility obtained was $0.06 \%$ and $0.08 \%$ o $(2 \sigma, n=137)$ for $\delta^{97 / 95} \mathrm{Mo}$ (here referred as $\delta^{97} \mathrm{Mo}$ ) and $\delta^{98} \mathrm{Mo}$, respectively, on an ICP internal standard solution (Techlab $\mathrm{n}^{\circ} \mathrm{B3015042)}$ (Fig. 2a). The reproducibility was $0.05 \%$ and $0.08 \%$ o $(2 \sigma, n=85)$ for $\delta^{97} \mathrm{Mo}$ and $\delta^{98} \mathrm{Mo}$, respectively, on a molybdenite matrix (Fig. 2b), corresponding to repeated analyses of the Henderson molybdenite (Reference Material 8599 for Re-Os, Markey et al., 2007). Both are equal to the reproducibility obtained in recent work on Mo-isotope analyses on molybdenites (e.g. Greber et al., 2014).

All data are reported as classic $\delta^{98} \mathrm{Mo}$ units relative to a standard solution according to the following formula:

$$
\delta^{98} \mathrm{Mo}=\left[\frac{(98 \mathrm{Mo} / 95 \mathrm{Mo}) \text { sample }}{(98 \mathrm{Mo} / 95 \mathrm{Mo}) \text { standard }}-1\right] * 1000 \quad \text { (Eq. 1) }
$$

Today, there is no internationally accepted standard and, in order to report our data in $\delta$-units, we used the NIST3134 solution (lot\#891307), which has been proposed as a reference for reporting Moisotopic compositions (Wen et al., 2010; Greber et al., 2012; Goldberg et al., 2013; Nägler et al 2013). Data are often reported as $\delta^{97} \mathrm{Mo}$, which is related to $\delta^{98} \mathrm{Mo}$ by the relation: $\delta^{97} \mathrm{Mo}=\frac{2}{3} \delta^{98} \mathrm{Mo}$ (Anbar, 2004). We tested the mean of $\delta^{97}$ Mo versus $\delta^{98}$ Mo for all samples analysed for this study, the mean values for Henderson molybdenite $\left(n=85,-0.13 \pm 0.05\right.$ and $-0.20 \pm 0.08 \%$ for $\delta^{97}$ Mo and $\delta^{98} M o$, respectively) and the ICP internal standard solution ( $n=137,-0.16 \pm 0.06$ and $-0.24 \pm 0.08 \%$ for $\delta^{97}$ Mo and $\delta^{98} \mathrm{Mo}$, respectively). The relationship obtained gave a graphical slope of the fractionation line at $1.480 \pm 0.004$, in full agreement with the expected value of 1.5 , demonstrating the validity of our corrections (see supplementary material).

Furthermore, four eluted fractions of a Sigma-Aldrich Mo solution as described in Wen et al. (2010) - who proposed such fractionated Mo solutions as secondary reference materials - were analysed by three laboratories (ENS-Lyon and CRPG Nancy in France, and LISG-MLR in China). During 
this study, we obtained mean $\delta^{98} \mathrm{Mo}_{\text {NIST }}$ values of $3.46 \pm 0.06 \%$ o $(n=30), 1.57 \pm 0.08 \%$ o $(n=33)$, $1.67 \pm 0.06 \%$ o $(n=33),-2.81 \pm 0.06 \%$ o $(n=32)$, respectively for solutions $1,2,3$ and 4 . The $\delta^{98} \mathrm{Mo}_{\text {NIST }}$ mean values cited in Wen et al. (2010) are respectively $3.24 \pm 0.35 \%, 1.42 \pm 0.41 \%$, $-1.63 \pm 0.29 \%$ ond $2.88 \pm 0.32 \%$ for the same solutions. Our results agree well with the measurements made in the three other laboratories (Fig. 3). Hereafter, the $\delta^{98}$ Mo calculated following eq. 1 , where the NIST3134 is used as standard is referred to as $\delta^{98} \mathrm{Mo}_{\mathrm{NIST}}$.

\section{Results and discussion}

For this study, 198 molybdenites were analysed and the results are listed in Table 2 . The following statistical analysis is based on our data (Table 2) and supplementary data from the literature $(n=193$; see table 2 in supplementary data). All data were converted to the NIST3134 standard in order to create internaly consistent database. Unfortunately, data from Pietruska et al. (2006) are could not be included because of a lack of intercalibration of their standard.

\section{1. $\delta^{98} \mathrm{Mo}_{\text {NIST }}$ variations and occurrence types}

Figure 4 illustrates the distribution of $\delta^{98} \mathrm{Mo}_{\text {NIST }}$ values for all data in our database, in addition with their discrimination according to the ten discriminated types of molybdenite occurrences/deposits; note that $\delta^{98} \mathrm{Mo}_{\text {NIST }}$ vary greatly from -1.62 to $2.27 \%$. For the main occurrence/deposit types, variations around $2 \%$ for the Mo isotopes can be seen in pegmatites, skarns or porphyry deposits, up to $2.6 \%$ for greisen and granites.

On Figure 4 we plotted also the mean values and standard deviations for the occurrence types. Even if small differences can be seen in the mean values, it is not possible to differentiate the occurrence/deposit types of molybdenite based on their $\delta^{98} \mathrm{Mo}_{\text {NIST }}$ values when considering the standard deviation of data (expressed as two standard deviations of the mean value).

Granite and porphyry deposits show lower $\delta^{98} \mathrm{Mo}_{\text {NIST }}$ mean values $(-0.15$ and $-0.17 \%$ ) than the other deposit types, while greisen $(1.00 \%, n=3)$ and IOCG $(0.82 \%, n=5)$ deposits show the highest mean 
values. Higher crystallization temperature of the former and lower of the latter group could explain these trends/variations. The reasons for Mo-isotope fractionation in molybdenite during magmatic and hydrothermal processes, however, are not well understood at present. Hannah et al. (2007) plead in favour of vapour transport and local Rayleigh distillation of Mo during molybdenite crystallization to explain the Mo isotope values in molybdenites. Although their arguments do not explain all measured values, Hannah et al. (2007) conclude that the "average isotopic composition of molybdenite from any one occurrence reflects that of continental crust." Even if the reasons explaining Mo-isotope fractionation in molybdenites remain relatively unknown, isotopic fractionation of Mo can be the result of several processes as recently discussed (Greber et al., 2014; Shafiei et al., 2014). Shafiei et al. (2014) recently evidenced that temperature is a parameter that can influence the partition of the fluid between liquid, vapour and saline brine. Another process leading to the fractionation of Mo isotopes concerns the structural polytype of molybdenite (Shafiei et al., 2014). Greber et al. (2014) discuss the preferential incorporation of Mo isotopes during fractional crystallization of minerals, the heavy Mo isotopes being preferentially incorporated into aqueous hydrothermal fluid, and the light Mo isotopes being incorporated into molybdenite crystals.

The large number of $\delta^{98} \mathrm{Mo}_{\text {NIST }}$ data in our database $(n=391)$ permits to run solid statistical analysis. The data distribution resembles the normal distribution (Fig. 5). Arithmetic mean and median, following the definition given in Meibom and Anderson (2003), are close each to other $(0.04 \pm 1.04 \%$ o $/ 2 \sigma /$ and $-0.04 \%$, respectively $)$, giving a good view of the distribution symmetry. The skewness of the data set is close to 0.62 , reflecting a slightly left-derived distribution; if the distribution would be symmetric, then the mean is equal to the median and the distribution will have zero skewness. In the end, the excess kurtosis was also calculated; this is an estimate of the peakedness of the distribution compared to a Gaussian one. The dataset have an excess kurtosis of 1.029, reflecting a distribution that resembles a Gaussian one (with an excess kurtosis of 0 ). The slightly positive value of the excess kurtosis indicates a moderately peaked distribution. A Gaussian (normal) distribution is often used in pattern-recognition problems as the best way of modeling the 
probability density of experimental data; it is the distribution of the disorder maximum among all possible distributions coupling a defined mean and variance. Therefore, applying Gaussian distribution to a data set helps avoiding particular cases.

The distribution fits well with a Gaussian curve (pointed line in Fig. 5) with an $R^{2}$ close to 0.52 . The Kolmogorov-Smirnov non-parametric test - used for testing the normality of the distribution - fits also with the assumption that the $\delta^{98} \mathrm{Mo}_{\text {NIST }}$ data distribution is Gaussian. Furthermore, the probability-probability plot (P-P plot) on Fig. 6, is a graph of the empirical cumulative-distribution function values plotted against the theoretical ones. This is a step function that jumps up by $1 / n$ at each of the $\mathrm{n}$ data points. The P-P plot is used for determining how well a specific distribution fits the observed data. This plot will be approximately linear if the specified theoretical distribution is the correct model. According to Figure 6, the quasi-linearity of the pattern shows that the measurements are normally distributed. However, irregularities in the peak and potential contribution of the outliers can be tested by calculating a reduced chi-square value. The value for a pure normally distributed data set should be 1 . The calculated value is 14 (e.g. $\times 2$ observed=391 divided by the number of degrees of freedom $v=27$ ) that reflects irregularities.

Another insight of this new data set concerns the implications for the global Mo cycle. Voegelin et al. (2014) postulate the difficulties in defining the Mo isotope composition of the upper continental crust. Following other investigations, they used an alternative approach to constrain the Mo-isotope signature of the bulk silicate crust by using molybdenite-isotope values. This assumption is based on the fact that molybdenite is the only mineral source of Mo and originates from crystallizing magma or from hydrothermal processes. Thus, molybdenite provides a robust proxy for a crustal Mo-isotope signature. Following Greber et al. (2011), Voegelin et al. (2014) used the published molybdenite Moisotope data and calculated the average value of $\delta^{98} \mathrm{Mo}_{\mathrm{NIST}}=0.15 \%$ o (after normalization to the NIST3134 at $0 \%$ ). This value is clearly different from the one we defined in this study (mean value of $0.04 \%$ ). Arguing like Voegelin et al. (2014), the wide variation of $\delta^{98} \mathrm{Mo}_{\mathrm{NIST}}$ over a few per mil 
precludes the use of molybdenite Mo-isotope ratios for constraining the value of the silicate crust. This is confirmed by the two standard deviations of the whole data set (1.04).

Our database helps investigating the nature of Mo-isotope fractionation, as well as testing any links with mineralizing processes. In order to demonstrate this we will focus on the granitepegmatite-perigranitic vein series. For these occurrences (Fig. 7), we see that the mean $\delta^{98} \mathrm{Mo}_{\text {NIST }}$ values evolve from granite $(-0.15 \% \pm 1.03, n=25)$ to pegmatite $\left(0.23 \% \_ \pm 1.05, n=80\right)$ and finally to perigranitic veins $(0.63 \% \pm 0.77, n=9)$. The mean greisen value is not significant for this comparison as only three values can be used for the calculation. Measurements of the arithmetic mean and median are close for individual molybdenite occurrences, with, respectively for the mean and the median, 0.16 and -0.27 for granite, 0.23 and 0.20 for pegmatite, and 0.63 and 0.69 for perigranitic veins. For each occurrence, the similarity of the mean and median values indicates a distribution symmetry. This is also documented by the coefficient of variation (CV), ranging from -3.2 for granite, 2.3 for pegmatite and 0.6 for perigranitic veins, measuring the dispersion of samples whose means are not equal. The skewness of the three data subsets are respectively close to $-0.22,0.20$ and -0.73 for granite, pegmatite and perigranitic veins. These values reflect a slightly left-derived distribution for the pegmatite and a slightly right-derived distribution for the granite and the perigranitic veins. The $\delta^{98} \mathrm{Mo}_{\text {NIST }}$ ratios of molybdenites have an excess kurtosis of respectively $2.39,-0.74$ and -0.23 for granite, pegmatite and perigranitic veins, reflecting distributions that resemble a Gaussian one (with an excess kurtosis of 0 ). The positive value for granite indicates a peaked distribution, while the slightly negative values for pegmatite and perigranitic veins indicates a more smoothed distribution.

Lower $\delta^{98} \mathrm{Mo}_{\text {NIST }}$ values (Figs. 4 and 7) are found in molybdenite-bearing granite, while perigranitic veins have the highest mean values. We used the Kruskal-Wallis analysis for comparing the $\delta^{98} \mathrm{Mo}_{\mathrm{NIST}}$ values obtained for these Mo occurrences, as the distribution of $\delta^{98} \mathrm{Mo}_{\text {NIST }}$ values does not meet the normality assumption. Indeed, if each distribution would be symmetric, then the mean might be equal to the median and the distribution will have zero skewness. The results of the Kruskal-Wallis analysis show two features: the $p$-value is $<0.05$ when comparing granite-related molybdenite with 
the rest, and it is $>0.05$ when comparing molybdenite from pegmatite and perigranitic veins. This suggests that the pegmatite - and perigranitic veins - molybdenite means are statistically equal, but that both differ from the value for granite-molybdenite. The fractionation processes for Mo isotopes could thus be higher when the temperature decreases (Greber et al., 2014).

Granites crystallize at temperatures between 600 and $1000^{\circ} \mathrm{C}$ and molybdenites can occur within the granitic intrusion, or in the surrounding rocks. The crystallization temperatures are between 350 ${ }^{\circ} \mathrm{C}$ to $450{ }^{\circ} \mathrm{C}$ for the pegmatites (London, 2009). Perigranitic veins form later than pegmatites, at the end of granite crystallizing stage when the crystallization temperature is lower, below the pneumatolytic to hydrothermal transition (about $374{ }^{\circ} \mathrm{C}$ ). Not only is the crystallization temperature close for molybdenite from pegmatites and perigranitic veins with comparable means, but it is different between granite-related molybdenite and molybdenite from pegmatites. This indicates that the crystallization temperature influences the $\delta^{98} \mathrm{Mo}_{\text {NIST }}$ values of granite-related occurrences. In addition, we can postulate that these differences, being related to the preferential incorporation of light Mo-isotopes during crystallization, will leave behind a melt enriched in heavier Mo isotopes. Greber et al. (2014) proposed this explanation at the occurrence scale, but with our new data we can extend this explanation to a larger scale.

Hannah et al. (2007) claimed no relationship between $\delta^{98} \mathrm{Mo}_{\text {NIST }}$ and the age of mineralization. In the new data set we obtained for this study, the samples came from all continents - especially new data from Russia and China - and cover Archean to "Recent" (<2 Ma) times. Again, no relationship was observed between the isotope ratio and the age of mineralization.

\subsection{Variability of $\delta^{98} \mathrm{Mo}_{\mathrm{NIST}}$ at occurrence scale}

For some occurrences, we could analyse $\delta^{98} \mathrm{Mo}_{\text {NIST }}$ values on several molybdenite samples. For the Bécon-les-Granits granite (Maine-et-Loire, France), from where five molybdenite samples were analysed, the $\delta^{98} \mathrm{Mo}_{\text {NIST }}$ variation is around $0.69 \%$. Alpine-type fissure veins show even larger 
variations close to $1.25 \%$, as observed for both Glacier de Bonne Pierre $(n=3)$ and Ravin de la Ruine $(n=3)$.

Focusing on data subset covering skarns, pegmatites and porphyry deposits, we applied the boxplots approach (Fig. 8). This uses the median, quartiles, and lowest and highest data points for conveying the level, spread, and symmetry of a distribution of data values, and is easily refined to identify outlier data values.

For the Azegour skarn (Morocco, Permingeat, 1959; Breillat et al., 2013), the $\delta^{98} \mathrm{Mo}_{\text {NIST }}$ values of the 29 molybdenite samples cover a large range of variations, around $0.7 \%$, from -0.60 to $0.42 \%$. Compared to the other skarn samples ( $n=42$; Fig. 8a), it is clear that the Azegour group is generally similar, the median being lower than the value for all 42 skarn samples (inclusive the Azegour), the minima being close for the two sample sets while the maxima are higher in the whole skarn population.

Considering the pegmatite occurrences, Figure $8 b$ shows the Alpajahorn site (Swiss Alps, $n=38$, Greber et al., 2011), the Grimsel Pass site (Swiss Alps, n=13, Greber et al., 2011), the Ploumanac'h pegmatite from Brittany (NW France; this study, $n=8)$ as well as the whole pegmatite data set $(n=80)$. Taken as a whole, the pegmatite population attains a median value of $0.21 \%$. The Ploumanac'h pegmatite $\delta^{98} \mathrm{Mo}_{\text {NIST }}$ varies slightly by only $0.22 \%$, between the lowest value $\left(\delta^{98} \mathrm{Mo}_{\text {NIST }}=-0.68 \%\right.$ o $)$ and the highest one $\left(\delta^{98} \mathrm{Mo}_{\mathrm{NIST}}=-0.46 \%\right.$ ), with median $\delta^{98} \mathrm{Mo}_{\mathrm{NIST}}$ values of around $-0.58 \%$ ond a clearly Gaussian data distribution. Compared to the whole data set, the Ploumanac'h pegmatite occupies the lowermost values. For the Alpajahorn site data distribution is clearly non-gaussian, Greber et al. (2011) argued that the most plausible Mo source is related to the circulation of hydrothermal fluids exsolved during late crystallization stages of the Central Aar Massif granite. For the Ploumanac'h pegmatite, the Mo source is similar - late residual magmatic fluids. Moreover, Greber et al. (2011) proposed redox variations of the mineralizing fluids as the main mechanism for explaining the isotopic variations in the Alpajahorn site. For the Ploumanac'h occurrence, the narrow range of data 
variation may reflect short transport distance of the fluid related to the proximity of the parent granite to the pegmatite-host.

For the porphyry occurrences $(n=180)$ the distribution is Gaussian. Fig. $8 c$ shows the data for a selected series of sites. These include the Butte deposit (Rusk et al., 2008; USA, $n=9$, this study), the Caosiyao deposit (China, $n=7$, this study), the Hashitu deposit (Zhai et al., 2014; China, $n=9$, this study), the Questa deposit (USA, $n=46$, this study and Greber et al., 2014), the Kerman deposit (Iran, $n=26$, Shafiei et al., 2014), the Bugdaya deposit (Kovalenker et al., 2011; Russia, $n=6$, this study), and the Zhireken deposit (Berzina and Sotnikov, 2010; Russia, $n=7$, this study). Statistical parameters for the box plot of the Zhireken, Kerman, Questa and Hashitu deposits show a clearly Gaussian distribution. Bugdaya, Butte and Cosiyao are clearly non-Gaussian distribution. Kerman deposit shows the largest variation $\left(\delta^{98} \mathrm{Mo}_{\text {NIST }} \min =-0.90 \%\right.$; $\max =1.04 \%$; median=-0.03\%o) almost identical to the range of the whole porphyry-deposit data set. For Butte deposits, outliers induce a mean value higher than the $75^{\text {th }}$ percentile. However, when comparing all sites - with the exception of Hashitu, the median values are close to that for porphyry deposits as a whole at $-0.22 \%$.

\subsection{Variability of $\delta^{98} \mathrm{Mo}_{\mathrm{NIST}}$ at sample scale}

Variations of the $\delta^{98} \mathrm{Mo}_{\text {NIS T }}$ at centimetre scale were observed by Hannah et al. (2007) and Greber et al. (2011). Several explanations are possible for this variability, including a late metamorphic event (marked by a multi-modality of $\delta^{98} \mathrm{Mo}_{\mathrm{NIST}}$, Greber et al., 2011); multi-stage crystallization of molybdenite identifiable by Re-Os dating of the molybdenites (Greber et al., 2014) with igneous and hydrothermal molybdenite and molybdenite crystallized in stockworks; and finally by a Rayleigh fractionation that could explain a variation of up to $0.6 \%$ (Hannah et al., 2007; Greber et al., 2014). We confirmed this by analysing different samples. First, two molybdenite samples from the Preissac pegmatite (Abitibi, Canada) were analysed; within the rock sample they were about $3 \mathrm{~cm}$ distant, but their $\delta^{98} \mathrm{Mo}_{\text {NIST }}$ values differed by $0.36 \%$, higher than the analytical uncertainty of $0.09 \%$. After that, we analysed two samples from the Moly Hill pegmatite (La Motte, Abitibi, Canada). In the first one, 
three molybdenite spots - about $2 \mathrm{~cm}$ distant - were analysed, displaying a $\delta^{98} \mathrm{Mo}_{\mathrm{NIST}}$ variation of around $0.30 \%$. In the second sample, three molybdenites - again about $2 \mathrm{~cm}$ distant- showed a variation of $0.22 \%$ in the $\delta^{98} \mathrm{Mo}_{\text {NIST }}$ values. It is clear that more work is needed to investigate the link between $\delta^{98} \mathrm{Mo}_{\text {NIST }}$ variations and the main causes of the fractionation processes, a work that was started with the Azegour case (Breillat et al., 2013).

\section{Conclusions}

We used variations in the Mo-isotopic composition in molybdenites $\left(\mathrm{MoS}_{2}\right)$ for studying the different types of ore deposits and particularly for understanding Mo fractionation during mineralizing processes.

A key question when using large data sets (combining data from this study and the literature) concerns the standard problem of normalizing data. As there is no international standard for Moisotopes, uncertainties remain when comparing data sets from different laboratories. To solve this potential problem, we used the NIST3134 - proposed as an international standard- to obtain meaningful access to different data deriving from world-wide molybdenite occurrences.

The molybdenite database used in this study thus comprises 391 Mo-isotope data, including 193 samples from the literature and 198 from this work. Thanks to this study, the number of available $\delta^{98} \mathrm{Mo}_{\text {NIST }}$ data for molybdenite has been more than doubled. The concerned ore-deposits are porphyries, skarns, pegmatites, perigranitic veins, greisen, Alpine-type fissure veins, IOCG, epithermal veins, and a few Mo samples of undetermined origin.

The obtained $\delta^{98} \mathrm{Mo}_{\text {NIST }}$ values varied greatly from -1.62 to $2.27 \%$, with the largest range for $\mathrm{MoS}_{2}$ of greisen and granite $(2.6 \%$ ). Differences can be seen in the mean values, but we could not differentiate $\delta^{98} \mathrm{Mo}_{\mathrm{NIST}}$ according to occurrence type when using two standard deviations of the mean value. The crystallization temperature can explain some variations, as perigranitic veins, greisen, Alpine-type fissure veins and polymetallic veins generally crystallize at lower temperatures than granite, pegmatite and porphyry deposits. Although most of studied deposits can form over a wide 
temperature range, granite, pegmatite, perigranitic veins and porphyry deposits usually show high formation temperatures, near to solidus temperatures of related magmas. Skarns and IOCG are more delicate, as sulphides can be deposited at various stages of the metasomatic process.

The 391 data set yielded a mean value of $0.04 \pm 1.04 \% \circ(2 \sigma)$ and a median value of $-0.04 \%$ o $\delta^{98} \mathrm{Mo}_{\mathrm{NIST}}$, both showing good symmetry in the distribution. This agrees with the data skewness, which reflects a slightly left-derived distribution, and the excess kurtosis that reflects a Gaussian and peaked distribution. The Kolmogorov-Smirnov nonparametric test for testing the distribution normality, confirmed the assumption that the distribution of all data is Gaussian.

A Kruskal-Wallis analysis of the $\delta^{98} \mathrm{Mo}_{\text {NIST }}$ molybdenite distribution of the granite-pegmatiteperigranitic veins data subsets confirmed that the mean values of pegmatite and perigranitic veins are statistically (test of the mean) undistinguishable, however, are different from that of granites. As proposed by Greber et al. (2014), we explain these differences by a preferential incorporation of light Mo isotopes into molybdenite during crystallization from an aqueous fluid, leaving a melt enriched in heavier Mo isotopes. In a granitic-perigranitic environment, a trend of average values can be drawn from highest to lowest temperatures: granite $(-0.13 \%)$, pegmatite $(0.23 \%)$, perigranitic veins $(0.63 \%)$ and greisen $(1.00 \% \circ)$. Other processes could explain these variations as Rayleigh fractionation (Hannah et al., 2007) and the structural type of molybdenites in the crystal structure (Shafiei et al., 2014).

It is important to work with the same standard for improving data reproducibility, and in order to have a better understanding of Mo-isotopic-composition variations at smaller scales. Thanks to the NIST3134 normalization, a huge data set could be compared. The large number of samples analysed for this study allowed refining the Mo-isotopic composition database, as the variations are smaller in our data set than in the literature data sets.

\section{Acknowledgments}


This work is part of the first author's PhD research supported by the Region Centre and the CarnotBRGM Institute. We thank Anne-Marie Desaulty, Anne-Marie Gallas and Michèle Robert for their help during laboratory work. Wen et al. are thanked for providing us with fractionated solutions. We acknowledge our BRGM colleagues Delphine Bruyère, Thierry Augé, Laurent Bailly, Wolfram Kloppmann and Johan Tuduri in helping us to find samples in the BRGM collection. Several colleagues from other institutes provided us with molybdenite samples or advice: Daniel P.S. de Oliveira (LNEG, Portugal), Richard Wanty (US Geological Survey, USA), Jeffrey Chiarerzelli (St. Lawrence University, USA), Michel Jébrak and Emilie Delpech (UQAM, Canada), Hans Isaksson (Geovista Luleå, Sweden), Degao Zhai (State Key Laboratory of Geological Processes and Mineral Resources, China, University of Geosciences, Beijing, China, Department of Geological Sciences, Indiana University, Bloomington, Indiana, USA), Anita Berzina (Institute of Geology and Mineralogy, Novosibirsk, Russia), Vladimir Kovalenker (Institute of Geology of Ore Deposits, Petrography, Mineralogy, and Geochemistry, Russian Academy of Sciences, Moscow, Russia), and Jianjun Liu (China University of Geosciences, Beijing, China). We are grateful to Dr. H.M. Kluijver for proofreading and editing the English text. A special thank goes to the anonymous reviewer, Ryan Mathur and the Associate Editor for constructive criticism.

\section{References}

Anbar, A.D., 2004. Molybdenum Stable Isotopes: Observations, Interpretations and Directions. Reviews in Mineralogy \& Geochemistry 55, 429-454.

Anbar, A.D., Knab, K.A., Barling, J., 2001. Precise determination of mass-dependent variations in the isotopic composition of molybdenum using MC-ICP-MS. Analytical Chemistry 73, 1425-1431, DOI: 10.1021/ac000829w.

Archer, C., Vance, D., 2008. The isotopic signature of the global riverine molybdenum flux and anoxia in the ancient oceans. Nature Geoscience 1, 597-600, DOI: 10.1038/ngeo282. 
Arnold, G.L., Anbar, A.D., Barling, J., Lyons, T.W., 2004. Molybdenum isotope evidence for widespread anoxia in mid-Proterozoic oceans. Science 304, 87-90, DOI: 10.1126/science.1091785.

Ballard, J.R., Palin, J.M., Williams, I.S., Campbell, I.H., Faunes, A., 2001. Two ages of porphyry intrusion resolved for the super-giant Chuquicamata copper deposit of northern Chile by ELA-ICPMS and SHRIMP. Geology 29, 383-386, DOI: 10.1130/00917613(2001)029<0383:TAOPIR>2.0.CO;2.

Barling, J., Arnold, G.L., Anbar, A.D., 2001. Natural mass-dependent variations in the isotopic composition of molybdenum. Earth and Planetary Science Letters 193, 447-457.

Bergman, S., Kubler, L., Martinsson, O., 2001. Description of Regional Geological and Geophysical Maps of Northern Norrbotten County (East of the Caledonian Orogen). Geological Survey of Sweden 56, 110.

Berzina, A., Sotnikov, V.I., 2010. Contribution from mafic melt to the Zhireken Porphyry Mo-Cu deposit, Eastern Transbaikalia, Russia: Evidence from mafic microgranular enclaves. International Journal of Economic and Environment Geology 1, 42-45.

Borrok, D.M., Nimick, D.A., Wanty, R.B., Ridley, W.I., 2008. Isotopic variations of dissolved copper and zinc in stream waters affected by historical mining. Geochimica et Cosmochimica Acta 72, 329344, DOI: 10.1016/j.gca.2007.11.014.

Breillat, N., Guerrot, C., Négrel, P., Marcoux, E., 2013. $\delta^{97 / 95}$ Mo in molybdenites from the Azegour skarn (Morocco). Goldschmidt Conference, August 25-30, Florence, Italy. Mineralogical Magazine $77,767$.

Chappaz, A., Lyons, T.W., Gordon, G.W., Anbar, A.D., 2012. Isotopic fingerprints of anthropogenic molybdenum in lake sediments. Environmental Science \& Technology 46, 10943-10940, DOI: dx.doi.org/10.1021/es3019379.

Chen, H., 2008. The Marcona - Mina Justa district, south-central Peru: Implications for the genesis and definition of the iron oxide-copper (-gold) ore deposit clan. PhD thesis, $280 \mathrm{p}$. 
Chen, W.T., Zhou, M.F, 2012. Paragenesis, stable isotopes, and molybdenite Re-Os isotope age of the Lala Iron-Copper Deposit, Southwest China. Economic Geology 107, 459-480, DOI: 10.2113/econgeo.107.3.459.

Cline, J.S., Bodnar, R.J., 1994. Direct evolution of brine from a crystallizing silicic melt at the Questa, New Mexico, molybdenum deposit. Economic Geology 89, 1780-1802, DOI: 10.2113/gsecongeo.89.8.1780.

Fersman, A.E., 1931. Über die geochemisch-genetische Klassifikation der Granitpegmatite. Tschermaks Mineralogische und Petrographische Mitteilungen 41, 64-83.

Geijer, P., 1924. Some Swedish Occurrences of Bornite and Chalcocite. Geological Survey of Sweden, $321,52$.

Geraghty, E.P., Carten, R.B., Walker, B.M., 1988. Tilting of Urad-Henderson and Climax porphyry molybdenum systems, central Colorado, as related to northern Rio Grande rift tectonics. Geological Society of America Bulletin 11, 1780-1786, DOI: 10.1130/00167606(1988)100<1780:TOUHAC>2.3.CO;2.

Goldberg, T., Gordon, G., Izon, G., Archer, C., Pearce, C.R., McManus, J., Anbar, A.D., Rehkämper, M., 2013. Resolution of inter-laboratory discrepancies in Mo isotope data: an intercalibration. Journal of Analytical Atomic Spectrometry 28, 724-735, DOI: 10.1039/C3JA30375F.

Greber, N.D., Hofmann, B.A., Voegelin, A.R., Villa, I.M., Nägler, T.F., 2011. Mo isotope composition in Mo-rich high- and low-T hydrothermal systems from the Swiss Alps. Geochimica et Cosmochimica Acta 75, 6600-6609, DOI: 10.1016/j.gca.2011.08.034.

Greber, N.D., Pettke, T., Nägler T.F., 2014. Magmatic-hydrothermal molybdenum isotope fractionation and its relevance to the igneous crustal signature. Lithos 190-191, 104-110, DOI: 10.1016/j.lithos.2013.11.006.

Greber, N.D., Siebert, C., Nägler, T.F., Pettke, T., 2012. $\delta^{98 / 95} \mathrm{Mo}$ values and molybdenum concentration data for NIST SRM 610, 612 and 3134: Towards a common protocol for reporting 
Mo data. Geostandards and Geoanalytical Research 36-3, 291-300, DOI: 10.1111/j.1751908X.2012.00160.x.

Grip, E., Frietsch, R., 1973. Ore Deposits in Sweden 2, Northern Sweden. Almqvist \& Wiksell, Stockholm, 295.

Hannah, J.L., Stein, H.J., Wieser, M.E., de Laeter, J.R., Varner, M.D., 2007. Molybdenum isotope variations in molybdenite: Vapor transport and Rayleigh fractionation of Mo. Geology 35, 703706, DOI: 10.1130/G23538A.1.

Hofmann, B.A., Helfer, M., Diamond, L.W., Villa, I.M., Frei, R., Eikenberg, J., 2004. Topography-driven hydrothermal breccia mineralization of pliocene age at Grimsel Pass, Aar massif, Central Swiss Alps. Schweizerische Mineralogische und Petrographische Mitteilungen 84, 271-302, 84, 271302.

Kovalenker, V.A., Kiseleva, G.D., Krylova, T.L., Andreeva, O.V., 2011. Mineralogy and ore formation conditions of the Bugdaya Au-bearing W-Mo porphyry deposit, Eastern Transbaikal region, Russia. Geology of Ore Deposits 53, 93-125, DOI: 10.1134/S1075701511020048.

Lane, S., Proemse, B.C., Tennant, A., Wieser, M.E., 2013. Concentration measurements and isotopic composition of airborne molybdenum collected in an urban environment. Analytical and Bioanalytical Chemistry 405, 2957-2963, DOI: 10.1007/s00216-012-6660-9.

Lee, D.C., Halliday, A.N., 1995. Precise determinations of the isotopic compositions and atomic weights of molybdenum, tellurium, tin and tungsten using ICP magnetic sector multiple collector mass spectrometry. International Journal of Mass Spectrometry and Ion Processes 146/147, 35 46, DOI: 10.1016/0168-1176(95)04201-U.

London, D., 2009. Pegmatites. The Canadian Mineralogist, Special Publication 10, 363.

Maksaev, V., Munizaga, F., McWilliams, M., Mathur, R., Ruiz, J., Fanning, M., 2004. New chronology for El Teniente, Chilean Andes, from U-Pb, 40Ar/39Ar, Re-Os, and fission-track dating: implications for the evolution of a supergiant porphyry Cu-Mo deposit. In: Sillitoe RH, Perello J, 
Vidal CE (eds) Andean metallogeny: new discoveries, concepts, and updates. SEG special publication 11. Society of Economic Geologists, Boulder, 15-54.

Malinovsky, D., Hammarlund, D., Ilyashuk, B., Martinsson, O., Gelting, J., 2007. Variations in the isotopic composition of molybdenum in freshwater lake systems. Chemical Geology 236, 181198, DOI: 10.1016/j.chemgeo.2006.09.006.

Malinovsky, D., Rodushkin, I., Baxter, D.C., Ingri, J., Öhlander, B., 2005. Molybdenum isotope ratio measurements on geological samples by MC-ICPMS. International Journal of Mass Spectrometry 245, 94-107, DOI: 10.1016/j.ijms.2005.07.007.

Markey R., Stein H.J., Hannah, J.L., Zimmerman, A., Selby, D., Creaser, R.A., 2007. Standardizing ReOs geochronology: A new molybdenite reference material (Henderson, USA) and the stoichiometry of Os salts. Chemical Geology 244, 74-87, DOI: 10.1016/j.chemgeo.2007.06.002.

Markl, G., Lahaye, Y., Schwinn, G., 2006. Copper isotopes as monitors of redox processes in hydrothermal mineralization. Geochimica et Cosmochimica Acta 70, 4215-4228, DOI: 10.1016/j.gca.2006.06.1369.

Marschik, R., Mathur, R., Ruiz, J., Leville, R., de Almeida, A.J., 2005. Late Archean Cu-Au-Mo mineralization at Gameleira and Serra Verde, Carajás Mineral Province, Brazil: constraints from Re-Os molybdenite ages. Miner Deposita 39, 983-991, DOI: 10.1007/s00126-004-0450-z.

Masterman, G.J., Cook, D.R., Berry, R.F., Clark, A.H., Archibald, D.A., Mathur, R., Walshe, J.L., Durán, M., 2004. ${ }^{40} \mathrm{Ar}-{ }^{39} \mathrm{Ar}$ and Re-Os geochronology of porphyry copper-molybdenum deposits and related copper-silver veins in the Collahuasi district, northern Chile. Economic Geology 99, 673690, DOI: 10.2113/99.4.673.

Mathur, R., Ruiz, J., Munizaga, F., 2001. Insights into Andean metallogenesis from the perspective of Re-Os analyses of sulfides. Extended Abstract in III SSAGI International Conference 3, 34-36.

Mathur, R., Titley, S., Ruiz, J., Gibbins, S., Friehauf, K., 2005. A Re-Os isotope study of sedimentary rocks and copper-gold ores from the Ertsberg District, West Papua, Indonesia. Ore Geology Reviews 26, 207-226, DOI: 10.1016/j.oregeorev.2004.07.001. 
Mathur, R., Brantley, S., Anbar, A., Munizaga, F., Maksaev, V., Newberry, R., Vervoort, J., Hart, G., 2010. Variation of Mo isotopes from molybdenite in high-temperature hydrothermal ore deposits. Mineralium Deposita 45, 43-50, DOI: 10.1007/s00126-009-0257-z.

Mathur, R., Munk, L., Nguyen, M., Gregory, M., Annell, H., Lang, J., 2013. Modern and Paleofluid Pathways Revealed by $\mathrm{Cu}$ Isotope Compositions in Surface Waters and Ores of the Pebble Porphyry Cu-Au-Mo Deposit, Alaska. Economic Geology 108, 529-541, DOI: 10.2113/econgeo.108.3.529. Mathur et al. 2013

Meibom, A., Anderson, D.L., 2003. The statistical upper mantle assemblage. Earth and Planetary Science Letters 217, 123-139, DOI: 10.1016/S0012-821X(03)00573-9.

Meinert, L.D., 1992. Skarns and skarn deposits. Geoscience Canada 19, 145-162.

Murthy, V.R., 1963. Elemental and isotopic abundances of molybdenum in some meteorites. Geochimica et Cosmochimica Acta 27, 1171-1178, DOI: 10.1016/0016-7037(63)90098-X.

Nägler, T.F., Anbar, A.D., Archer, C., Goldberg, T., Gordon, G.W., Greber, N.D., Siebert, C., Sohrin, Y., Vance, D., 2013. Proposal for an international molybdenum isotope measurement standard and data representation. Geostandards and Geoanalytical Research 38, 149-151, DOI: 10.1111/j.1751-908X.2013.00275.x.

Neubert, N., Heri, A.R., Voegelin, A.R., Nägler, T.F., Schlunegger, F., Villa, I.M., 2011. The molybdenum isotopic composition in river water: Constraints from small catchments. Earth and Planetary Science Letters 304, 180-190, DOI: 10.1016/j.epsl.2011.02.001.

Öhlander, B., 1986. Proterozoic Mineralizations Associated with Granitoids in Northern Sweden. Geological Survey of Sweden, 65, 39.

Ossandón, C.G., Fréraut, C.R., Gustafson, L.B., Lindsay, D.D., Zentilli, M., 2001. Geology of the Chuquicamata Mine: A Progress Report. Economic Geology 96, 249-270, DOI: 10.2113/gsecongeo.96.2.249.

Permingeat, F., 1959. Le gisement de molybdène, tungsten et cuivre d'Azegour (Haut Atlas) : Etude pétrographique et métallogénique. Notes et Mémoires SGM 141, PhD thesis, 290 p. 
Pierotti, G., Mathur, R., Smith, R.C., Barra, F., 2006. Re-Os molybdenite ages for the Antietam Reservoir, Eastern PA, A story of opensystem behavior of Re-Os isotopes in molybdenite. GSA Abstracts with Programs 38.

Pietruszka, A.J., Walker, R.J., Candela, P.A., 2006. Determination of mass-dependent molybdenum isotopic variations by MC-ICP-MS: An evaluation of matrix effects. Chemical Geology 225, $121-$ 136, DOI: 10.1016/j.chemgeo.2005.09.002.

Ray, G.E., Lefebure, D.V., 1999. A Synopsis of iron oxide $\pm \mathrm{Cu} \pm \mathrm{Au} \pm \mathrm{P} \pm$ REE deposits of the Candelaria-Kiruna-Olympic Dam family. Geological Fieldwork 2000-1, 267-271.

Redmond, P.B., Einaudi, M.T., 2010. The Bingham Canyon porphyry Cu-Mo-Au Deposit. I. Sequence of intrusions, vein formation, and sulfide deposition. Economic Geology 105, 43-68, DOI: 10.2113/gsecongeo.105.1.43.

Rosera, J.M., Coleman, D.S., Stein, H.J., 2013. Re-evaluating genetic models for porphyry Mo mineralization at Questa, New Mexico: implications for ore deposition following silicic ignimbrite eruption. Geochemistry, Geophysics, Geosystems 14-4, 785-805, DOI: 10.1002/ggge.20048.

Rusk, B.G., Reed, M.H., Dilles, J.H., 2008. Fluid-inclusion evidence for magmatic-hydrothermal fluid evolution in the porphyry copper-molybdenum deposit at Butte, Montana. Economic Geology 103, 307-333, DOI: 10.2113/gsecongeo.103.2.307.

Schaltegger, U., Corfu, F., 1992. The age and source of late Hercynian magmatism in the Central Alps - evidence from precise $\mathrm{U}-\mathrm{Pb}$ ages and initial Hf isotopes. Contributions to Mineralogy and Petrology, 111-3, 329-344, DOI: 10.1007/BF00311195.

Shafiei, B., Shamanian, G., Mathur, R., Mirnejad, H., 2014. Mo isotope fractionation during hydrothermal evolution of porphyry Cu systems. Mineralium Deposita, DOI: 10.1007/s00126014-0537-0.

Siebert, C., Nägler, T.F., von Blanckenburg, F., Kramers, J.D., 2003. Molybdenum isotope records as a potential new proxy for paleoceanography. Earth and Planetary Science Letters 211, 159-171, DOI: 10.1016/S0012-821X(03)00189-4. 
Siebert, S., Nägler, T.F., Kramers, J.D., 2001. Determination of molybdenum isotope fractionation by double-spike multicollector inductively coupled plasma mass spectrometry. Geochemistry Geophysics Geosystems 2, paper number 2000GC000124, DOI: 10.1029/2000GC000124.

Simmons, S.F., White, N.C., John, D.A., 2005. Geological characteristics of epithermal precious and base metal deposits. Economic Geology $100^{\text {th }}$ Anniversary Volume 1905-2005, 485-522.

Voegelin, A.R., Pettke, T., Greber, N.D., von Niederhäusern, B., Nägler, T.F., 2014. Magma differentiation fractionates Mo isotope ratios: Evidence from the Kos Plateau Tuff (Aegean Arc). Lithos 190-191, 440-448, DOI: 10.1016/j.lithos.2013.12.016.

Wallmach, T., Hatton, C.J., Droop, G.T.R, 1989. Extreme facies of contact metamorphism developed in calc-silicate xenoliths in the eastern Bushveld Complex. Canadian Mineralogist 27, 509-523.

Wanhainen, C., Billström, K., Stein, H., Martinsson, O., Nordin, R., 2005. 160 Ma of magmatic/hydrothermal and metamorphic activity in the Gällivare area: Re-Os dating of molybdenite and $\mathrm{U}-\mathrm{Pb}$ dating of titanite from the Aitik $\mathrm{Cu}-\mathrm{Au}-\mathrm{Ag}$ deposit, northern Sweden. Mineralium Deposita 40-4, 435-447, DOI : 10.1007/s00126-005-0006-x.

Wen, H., Carignan, J., Cloquet, C., Zhu, X., Zhang, Y., 2010. Isotopic delta values of molybdenum standard reference and prepared solutions measured by MC-ICP-MS: Proposition for delta zero and secondary references. Journal of Analytical Atomic Spectrometry 25, 716-721, DOI: 10.1039/B921060A.

Wieser, M.E., De Laeter, J.R., 2000. Thermal ionization mass spectrometry of molybdenum isotopes. International Journal of Mass Spectrometry 197, 253-261.

Wieser, M.E., de Laeter, J.R., 2003. A preliminary study of isotope fractionation in molybdenites. International Journal of Mass Spectrometry 225, 177-183.

Zhai, D., Liu, J., Wang, J., Yang, Y., Zhang, H., Wang, X., Zhang, Q., Wang, G., Liu, Z., 2014. Zircon U-Pb and molybdenite Re-Os geochronology, and whole-rock geochemistry of the Hashitu molybdenum deposit and host granitoids, Inner Mongolia, NE China. Journal of Asian Earth Sciences 79, 144-160, DOI: 10.1016/j.jseaes.2013.09.008. 
Zhu, X.K., Guo, Y., Williams, R.J.P., O'Nions, R.K., Matthews, A., Belshaw, N.S., Canters, G.W., de Waal, E.C., Weser, U., Burges,s B.K., Salvato, B., 2002. Mass fractionation processes of transition metal isotopes. Earth and Planetary Science Letters 200, 47-62, DOI: 10.1016/S0012-821X(02)00615-5. 


\section{Figure captions}

Figure 1: Worldwide distribution of analysed molybdenite samples. Red points ( $n=198$ ) are data from this study and green points are data from the literature $(n=193)$.

Figure 2: Long-term reproducibility of the $\delta^{98} \mathrm{Mo}:$ a) ICP standard solution (Techlab $\left.{ }^{\circ}{ }^{\circ} 3015042\right)$ : $2 \sigma=0.08 \%$ ( $n=137) ;$ and $b)$ Henderson molybdenite $8599: 2 \sigma=0.08 \%$ o $(n=85)$.

Figure 3: Plot of $\delta^{97} \mathrm{Mo}_{\text {NIST }}$ versus $\delta^{98} \mathrm{Mo}_{\text {NIST }}$ values ${ }_{\text {NIST }}$ of four fractionated solutions, and comparison with the results obtained at ENS-Lyon, CRPG Nancy and LISG-MLR (Wen et al., 2010). All data are plotted on the theoretical mass-fractionation line.

Figure 4: $\delta^{98} \mathrm{Mo}_{\text {NIST }}$ variations of molybdenite for the different occurrence/deposit types: granite, pegmatite, perigranitic vein, greisen, porphyry deposit, skarn, Alpine-type fissure vein, IOCG, polymetallic epithermal vein and unknown origin (this study and the literature, see text for details). Number of samples, mean value and $2 \sigma$ (standard deviation) are given for each occurrence/deposit type.

Figure 5: Histogram of $\delta^{98} \mathrm{Mo}_{\text {NIST }}$ ratios of molybdenite in the different occurrence types (same list as Fig. 4). The curve (dotted line) indicates the Gaussian distribution that best fits the observed data: mean $=0.04 ; 2 \sigma($ standard deviation $)=1.04$.

Figure 6: Probability-Probability (P-P) plot showing the fit with a normal law with a mean value of $0.04 \%$ and a $2 \sigma$ of $1.04 \%$.

Figure 7: Histogram of $\delta^{98} \mathrm{Mo}_{\text {NIST }}$ ratios of $\mathrm{MoS}_{2}$ in granite, pegmatite and perigranitic vein. The curve (dotted line) indicates the Gaussian distribution for each deposit type that best fits the observed data.

Figure 8: Box plots of $\delta^{98} \mathrm{Mo}_{\text {NIST }}$ ratios in molybdenites according to the occurrence types (this study and the literature, see text for details); a) skarn, b) pegmatite and c) porphyry deposit. The red vertical line represents the mean value and the black vertical line the median value; the box represents $1^{\text {st }}$ and $3^{\text {rd }}$ quartiles. The horizontal line corresponds to minimum and maximum accepted values. The symbols mark outliers.

\section{Table captions}

Table 1: Description of the occurrences analysed in this study, including seven samples from six localities without enough information concerning the occurrence type or even the precise location, referred to hereafter as 'undefined'. References to sub samples are indicated by an additional 
subscript a to d, meaning up to 4 subsamples, i.e. same rock sample referred MoXXX and up to 4 samples of molybdenite grain in the samples MoXXX.

Table 2: Mo-isotope data of molybdenites analysed for this study. Data are relative to NIST3134 $\left(\delta^{98} \mathrm{Mo}=0\right)$. Long-term external reproducibility of $0.08 \%$ o $(2 \sigma)$ on $\delta^{98} \mathrm{Mo}$. 


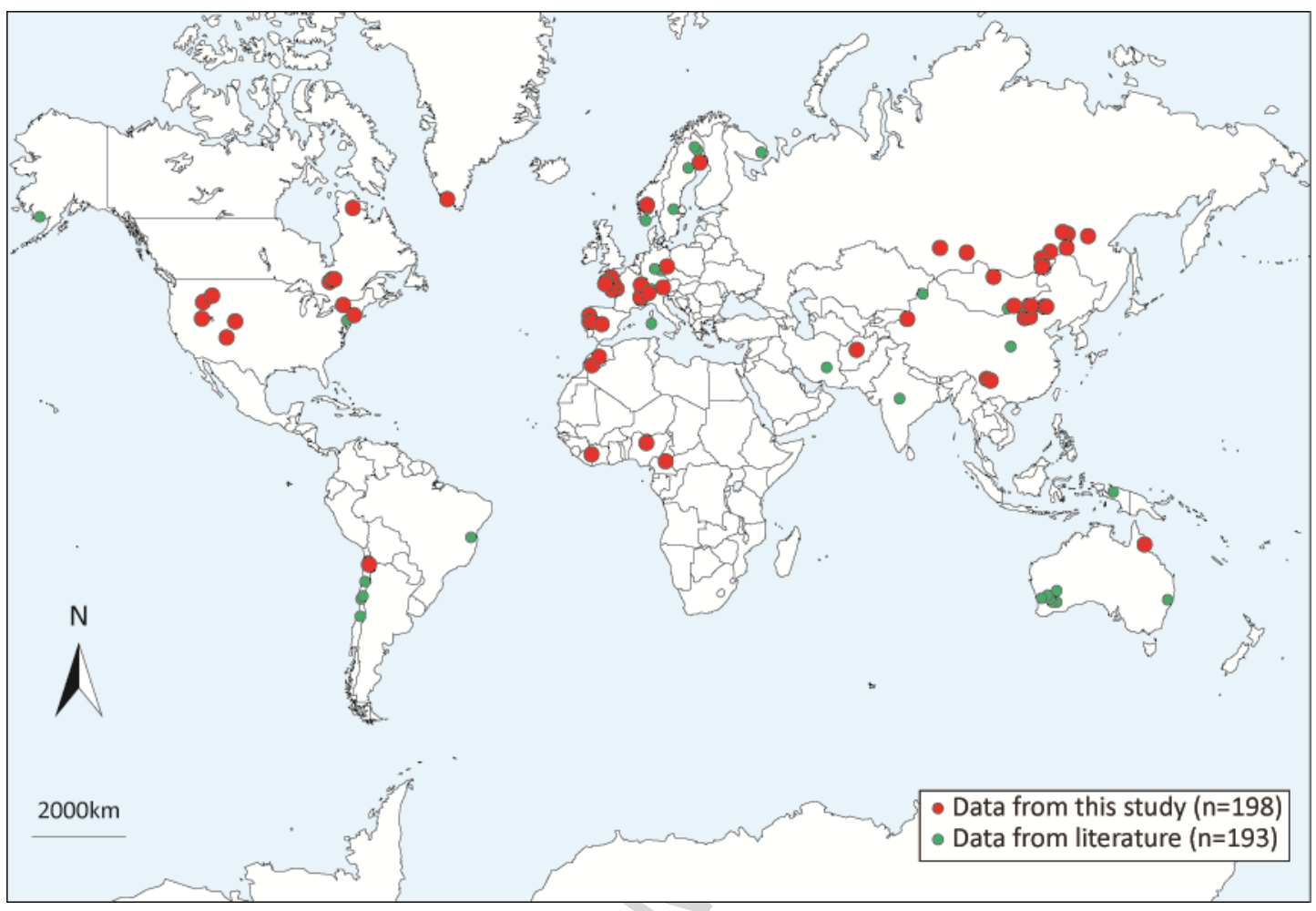

Figure 1 


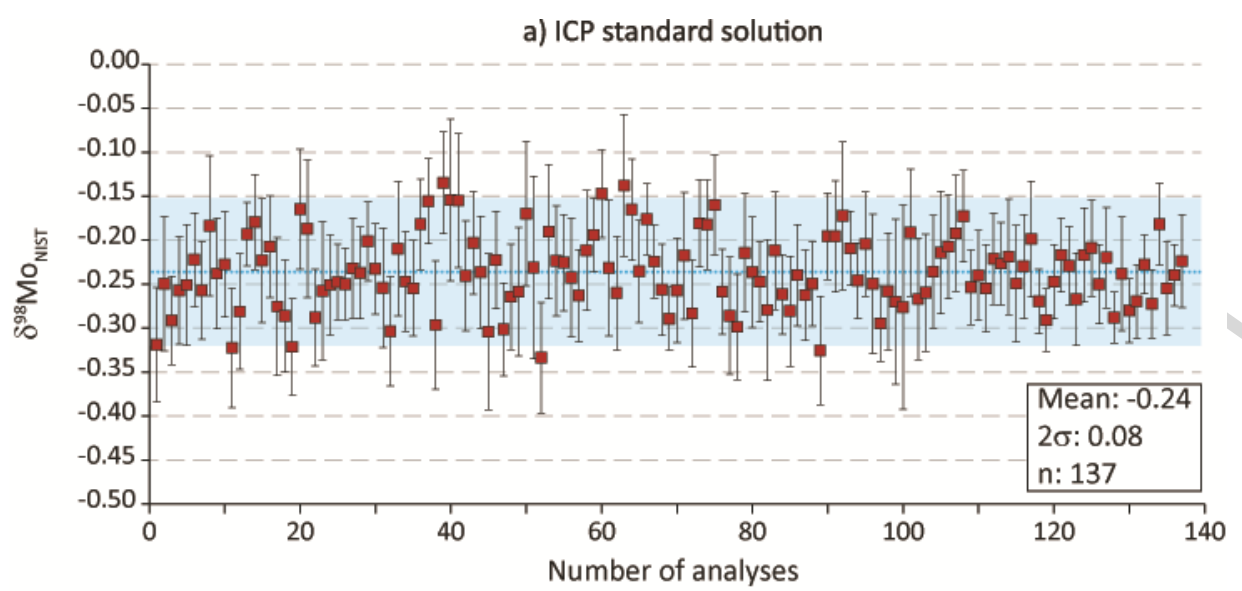

b) Henderson Molybdenite

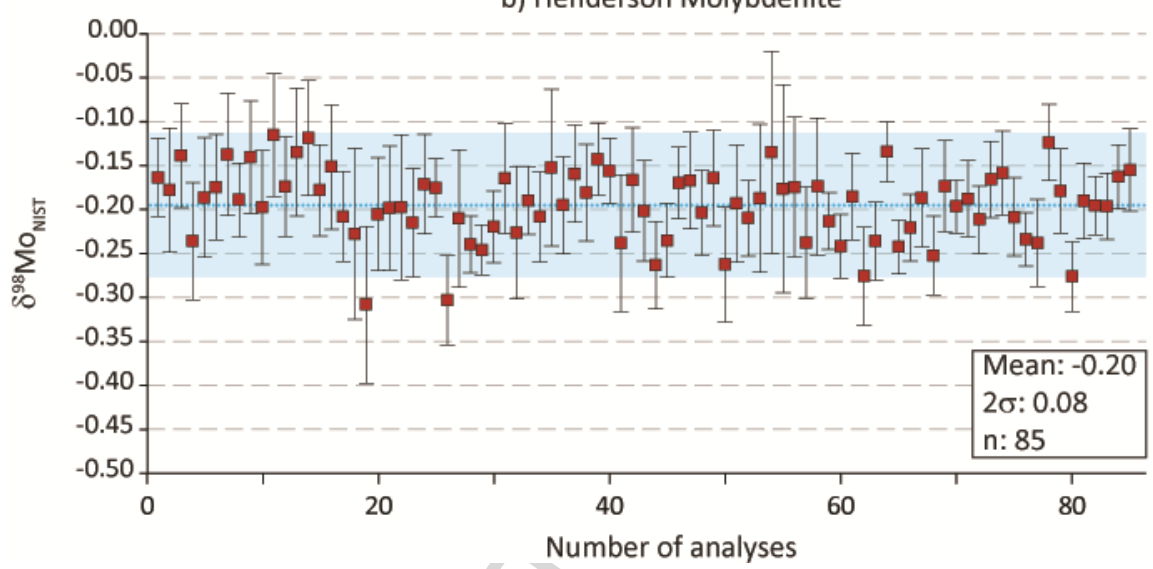

Figure 2 


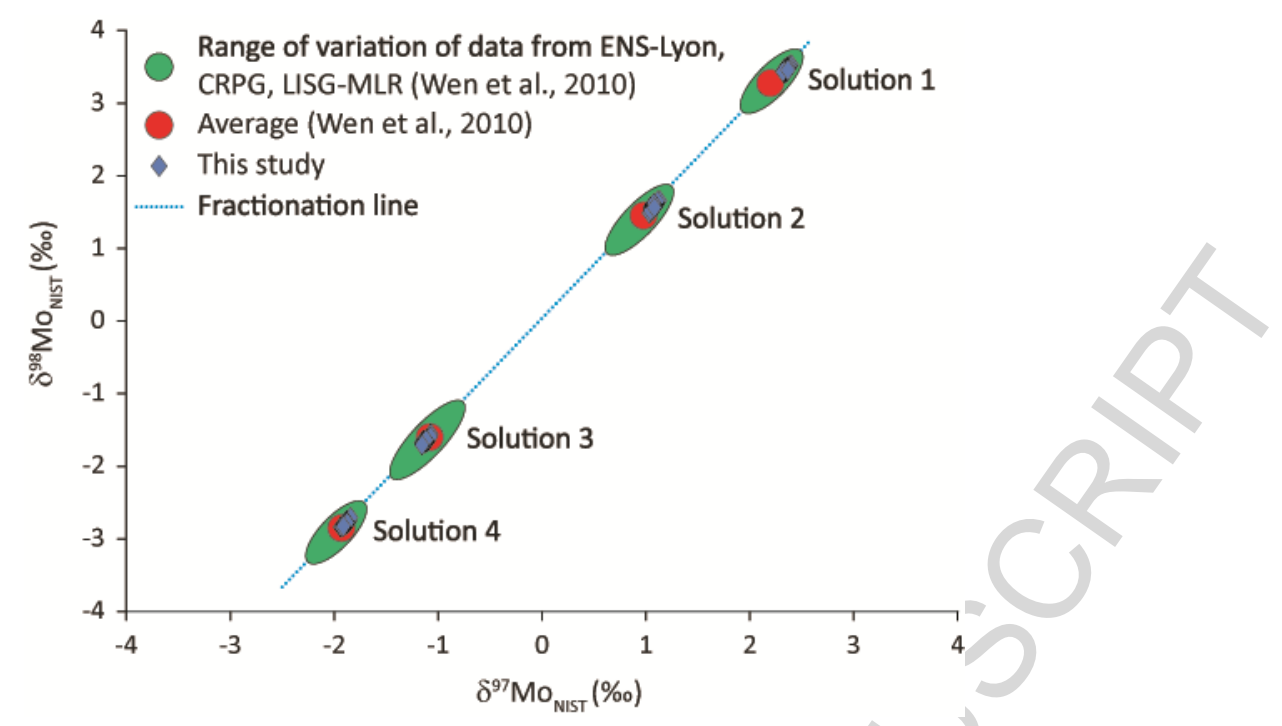

Figure 3 


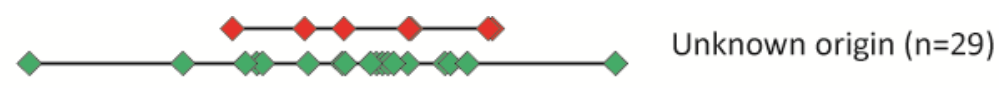

$\prec$ Polymetallic epithermal veins $(n=2$, mean $=0.68 \pm 0.40)$

$\leadsto \operatorname{IOGC}(\mathrm{n}=6$, mean $=0.82 \pm 1.22)$

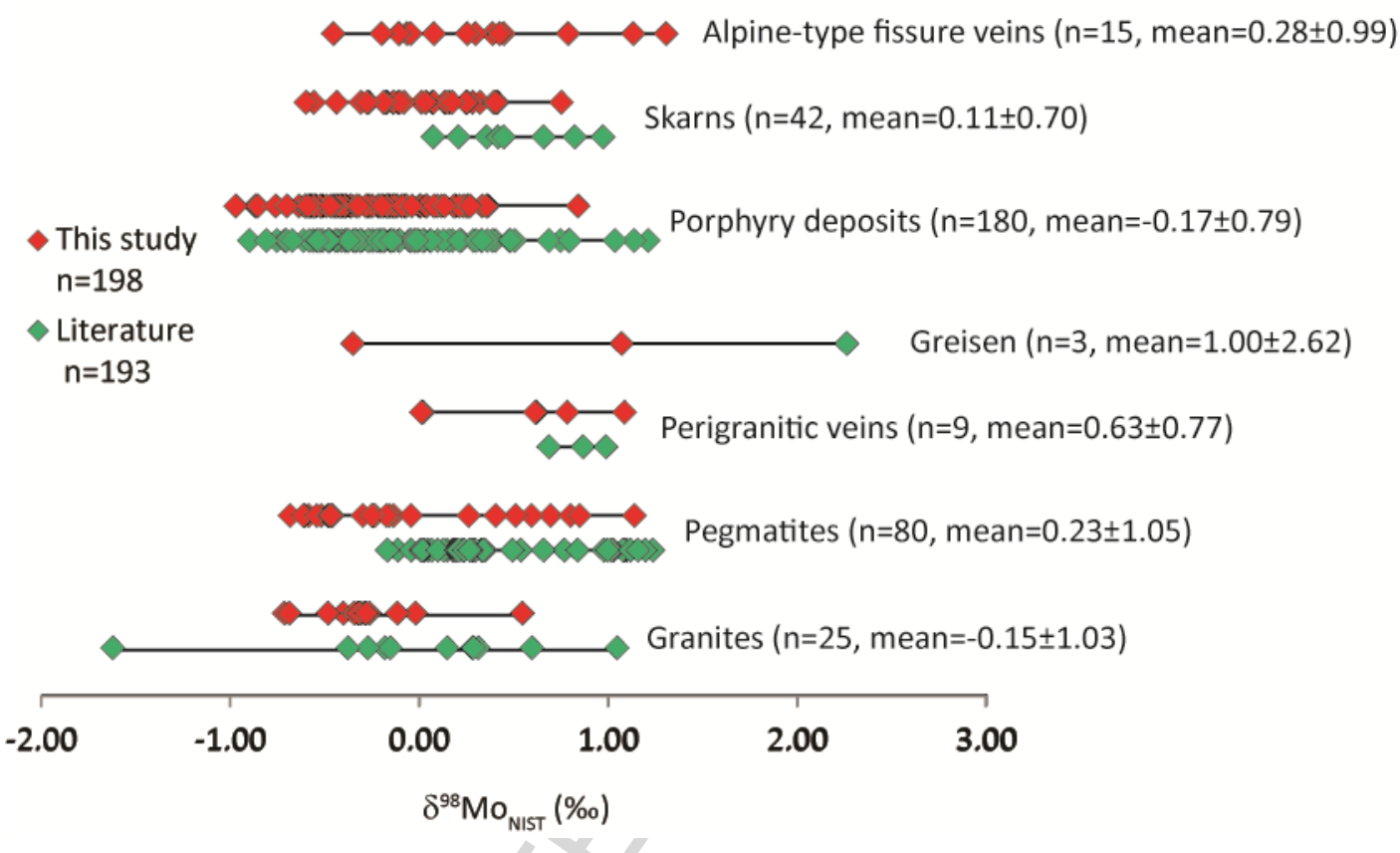

Figure 4 


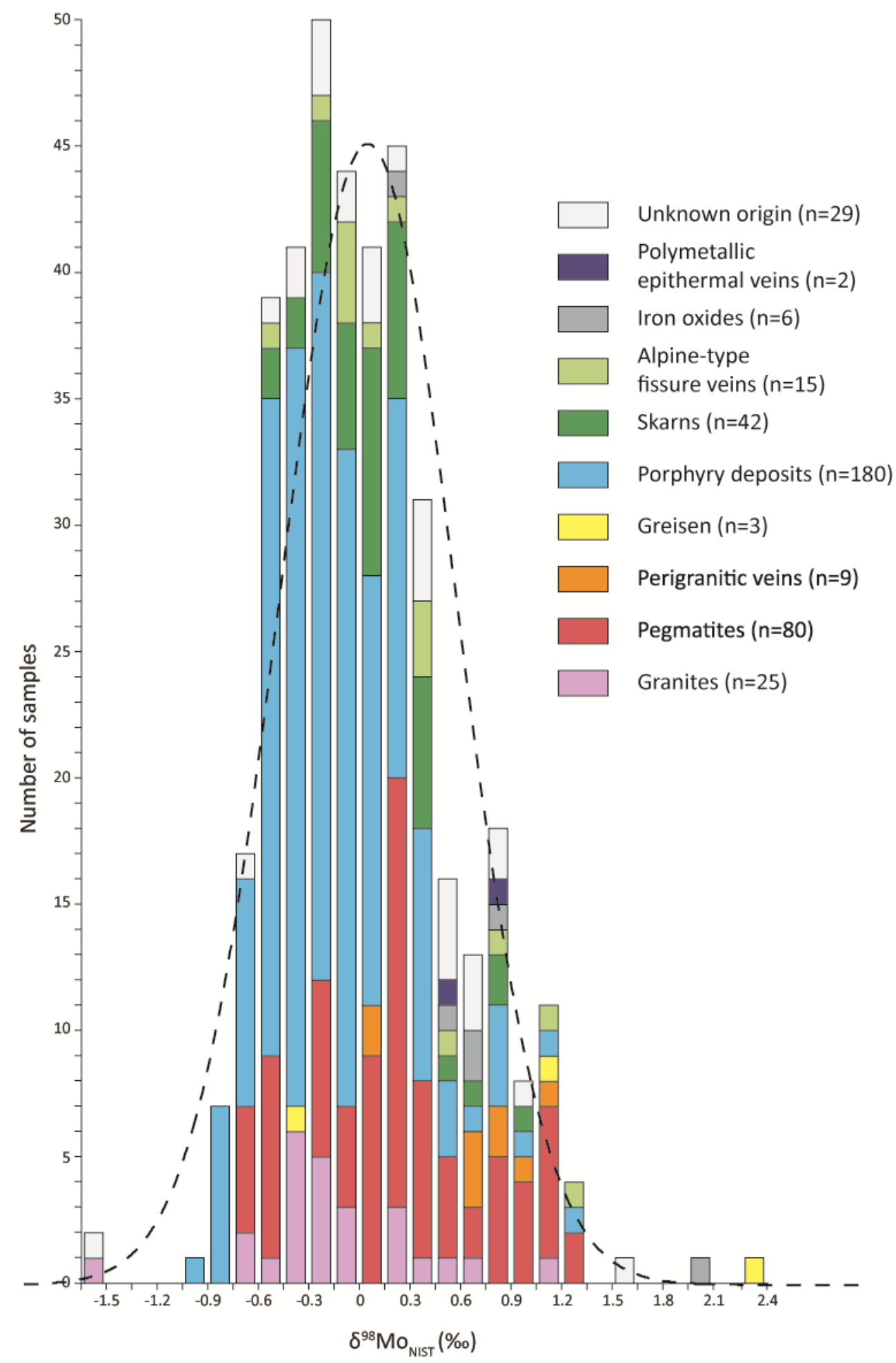

Figure 5 


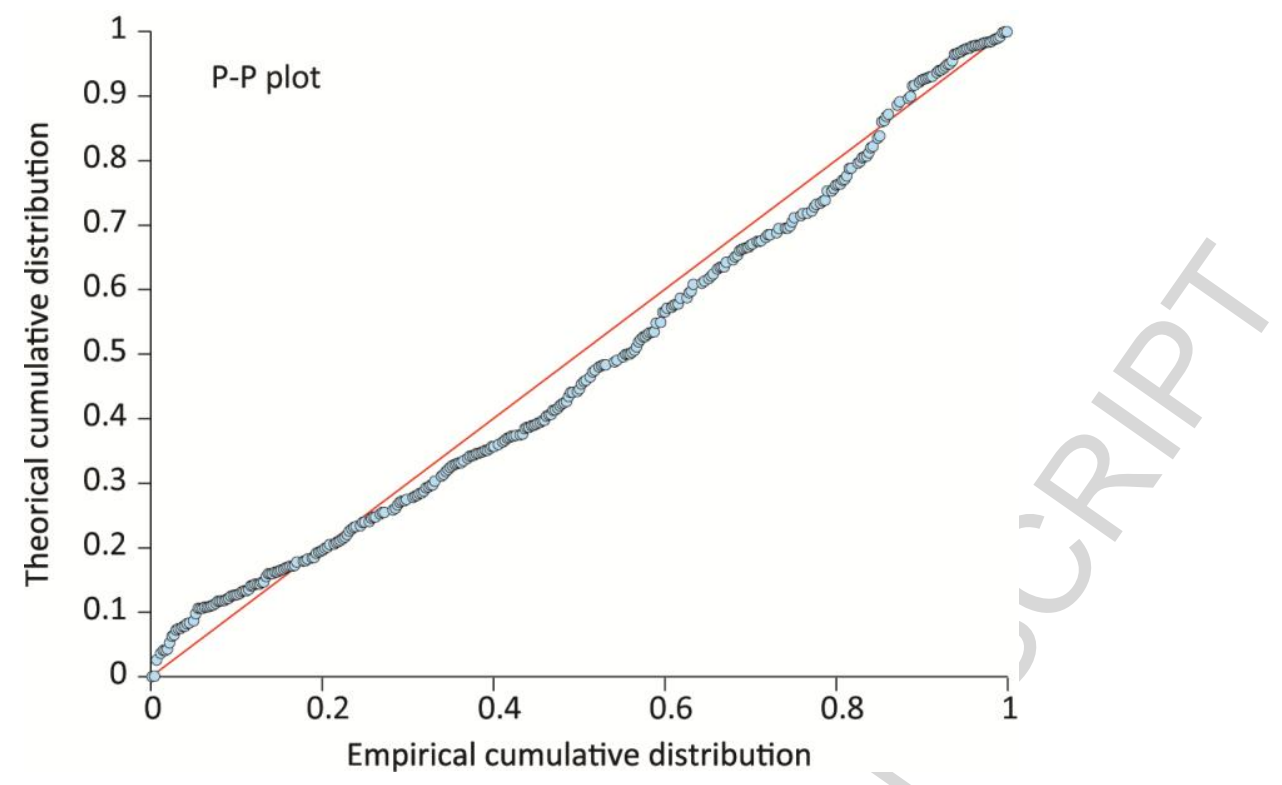

Figure 6 

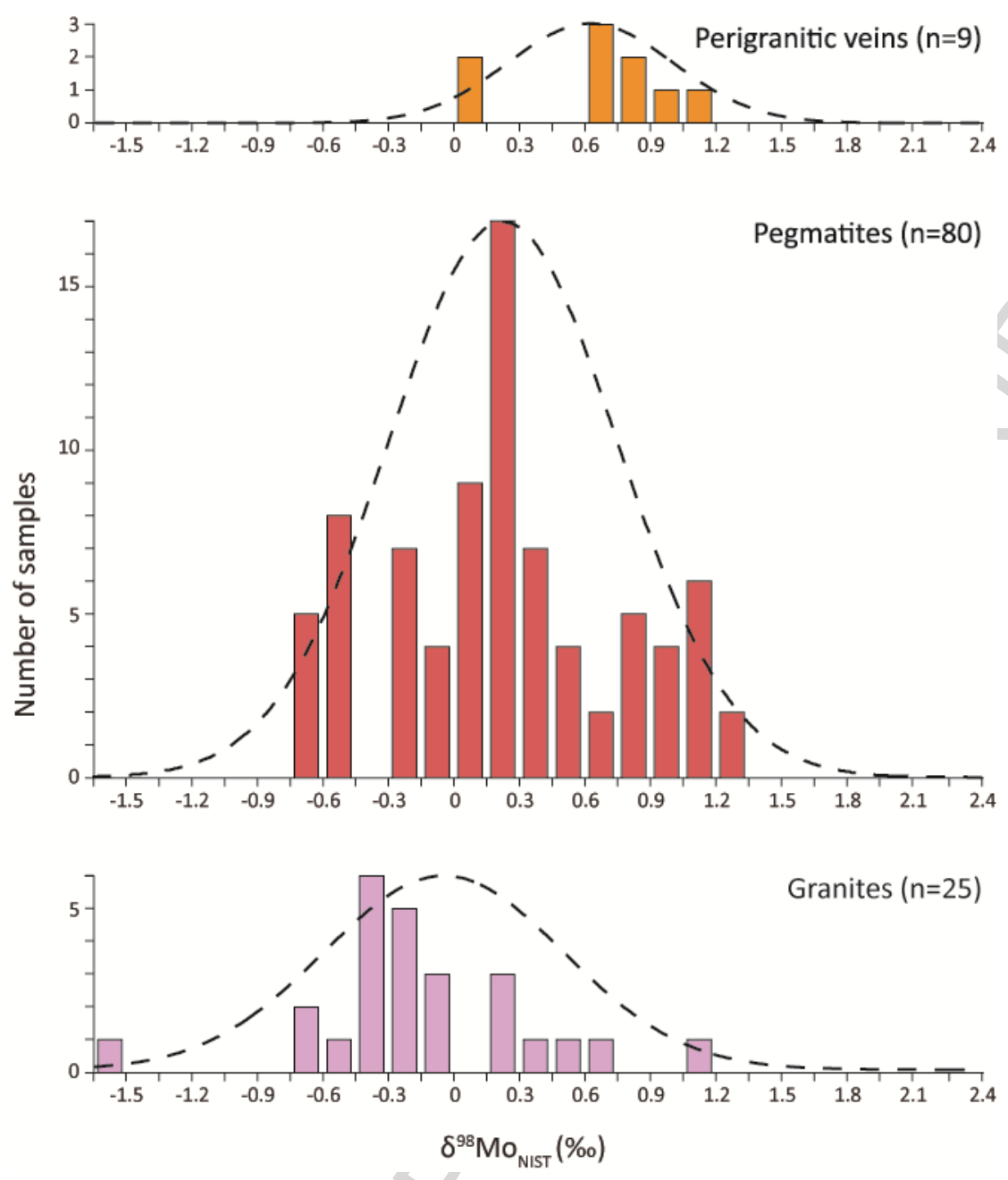

Figure 7 

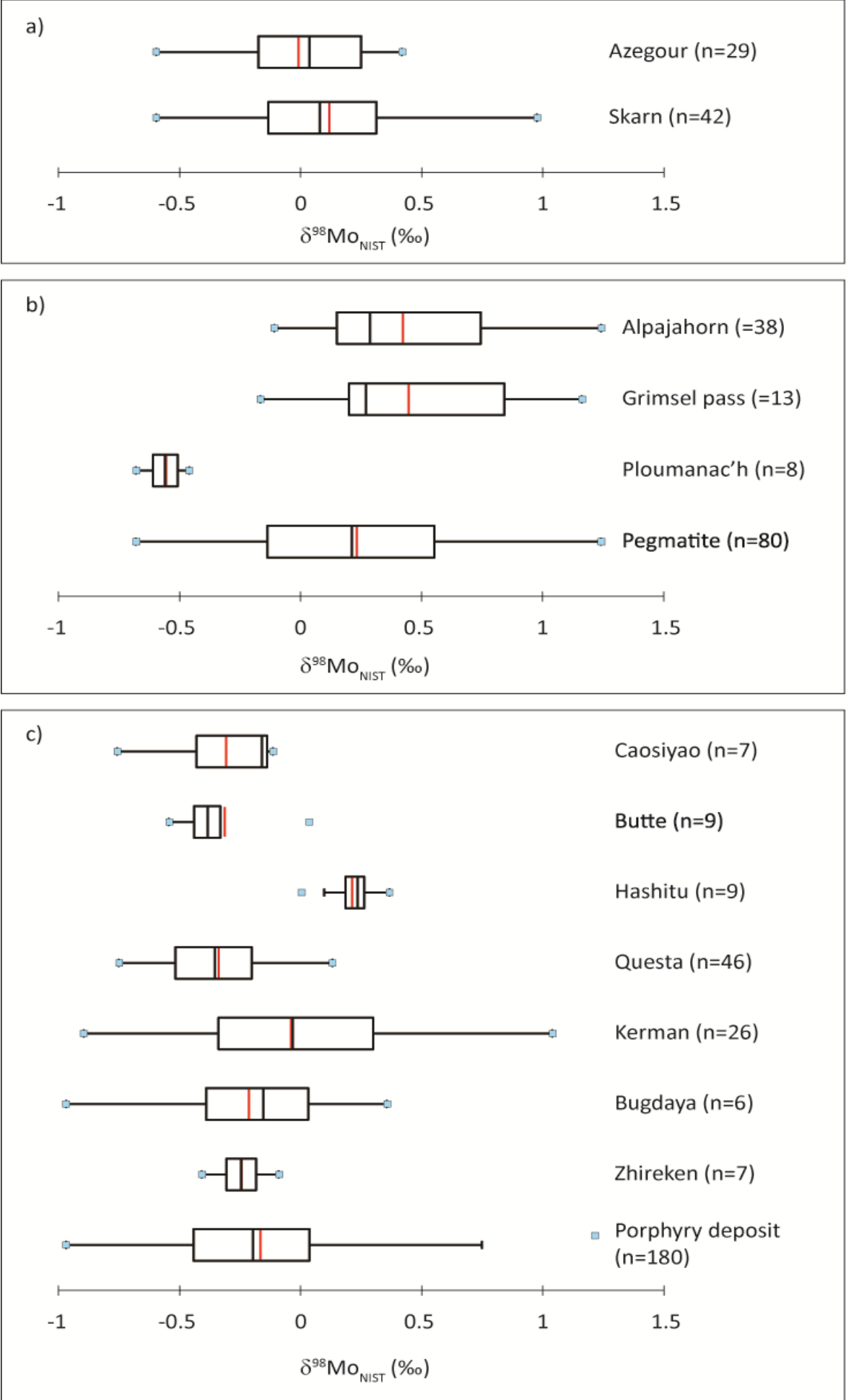

Figure 8 
Table 1

\begin{tabular}{|c|c|c|c|c|c|}
\hline \multicolumn{2}{|c|}{$\begin{array}{l}\overline{\text { Occurre }} \\
\text { nce type } \mathrm{T}^{\circ} \mathrm{C}\end{array}$} & ID & Location & Mineral assemblage & Age \\
\hline \multirow{11}{*}{ Granite } & & Mo001 & Kigom, Nigeria & Quartz vein with galena and silver & $\begin{array}{l}164 \pm 4 \mathrm{Ma} \\
327-315 \mathrm{Ma}\end{array}$ \\
\hline & & Mo032 & Becon les granits, Maine-et-Loire, France & & $327-315 \mathrm{Ma}$ \\
\hline & & Мo033 & Becon les granits, Maine-et-Loire, France & & $327-315 \mathrm{Ma}$ \\
\hline & & Mo034 & Becon les granits, Maine-et-Lc & & $327-315 \mathrm{Ma}$ \\
\hline & & Mo053 & Becon les granits, Maine-et-Loire, France & & $327-315 \mathrm{Ma}$ \\
\hline & $\begin{array}{l}<400- \\
600^{\circ} \mathrm{C}\end{array}$ & Mo039 & Man Departement, Ivory & Pyroxene, molybdenite & $\begin{array}{l}\text { Archean - } \\
\text { Proterozoic }\end{array}$ \\
\hline & & Mo046 & Bamiyan valley, Afghanistan & & $\begin{array}{l}\text { Upper Triassic to } \\
\text { Liassic }\end{array}$ \\
\hline & & Mo047 & Traouiéros, Côtes d'Armor, France & & $303 \pm 15 \mathrm{Ma}$ \\
\hline & & Mo167 & Wurinitu, Inner Mongolia, China & & $120-140 \mathrm{Ma}$ \\
\hline & & Mo168 & Wurinitu, Inner Mongolia, China & & $120-140 \mathrm{Ma}$ \\
\hline & & Mo169 & Wurinitu, Inner Mongolia, China & & $120-140 \mathrm{Ma}$ \\
\hline
\end{tabular}


Mo171 Wurinitu, Inner Mongolia, China

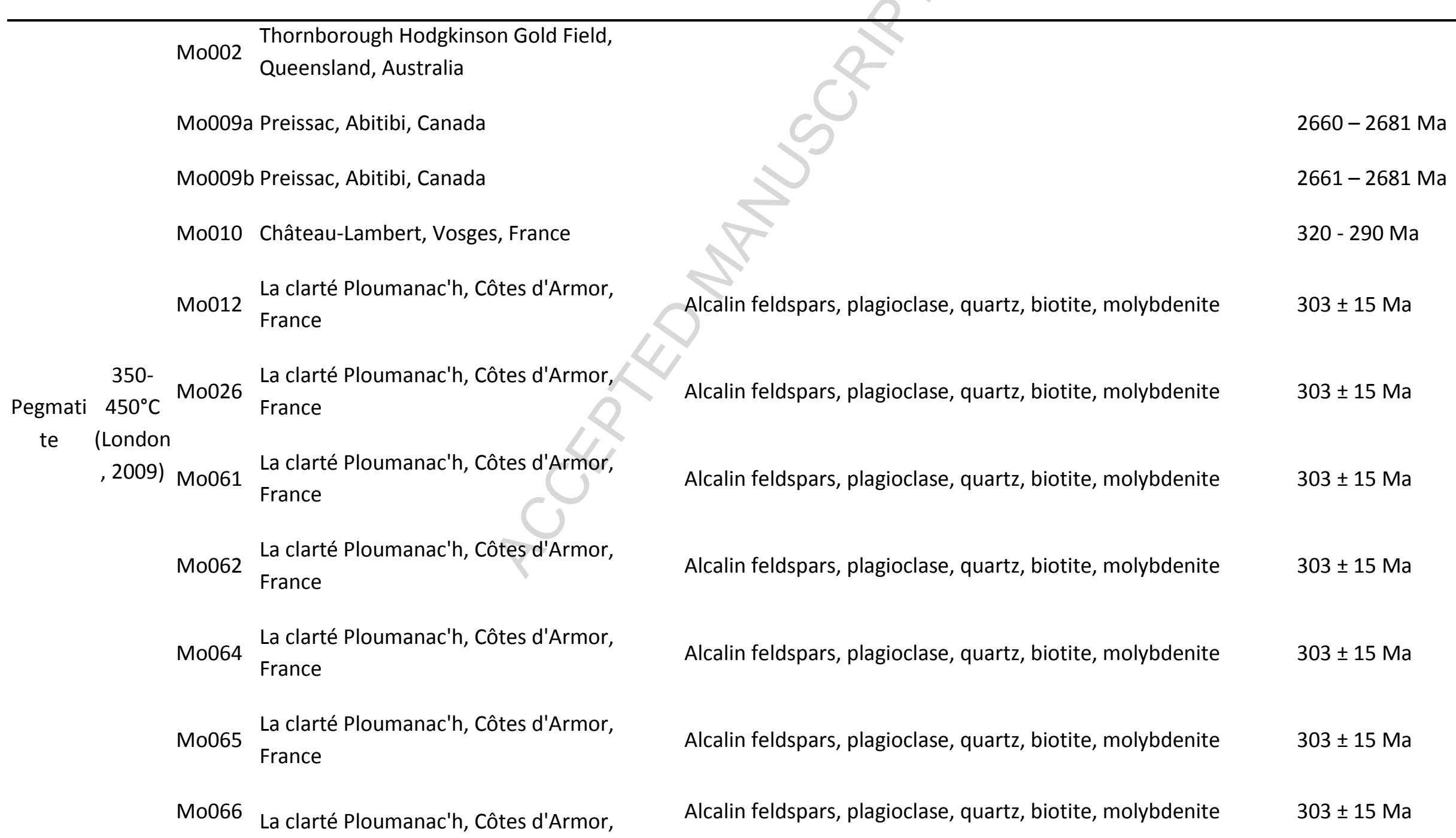




\section{France}

Mo067

La clarté Ploumanac'h, Côtes d'Armor, France

Mo045 Nunavik, Québec, Canada

Mo048 Menez Goaillou, France

Mo049 Läven, Norway

Mo050 Ivigtut, Arsuk, Greenland

Mo051 Ivigtut, Arsuk, Greenland

Mo052 Ivigtut, Arsuk, Greenland

Cubos e Chao do Castanheiro, Mangualde, Portugal

Mo094 Sunderbyn, Luleå area, Sweden

Mo095 Sunderbyn, Luleå area, Sweden

Mo096 Sunderbyn, Luleå area, Sweden

Mo097 Sunderbyn, Luleå area, Sweden

Mo120a Moly Hill mine, La Motte, Abitibi, Canada

Mo120b Moly Hill mine, La Motte, Abitibi, Canada
Alcalin feldspars, plagioclase, quartz, biotite, molybdenite

$303 \pm 15 \mathrm{Ma}$

Micas, biotite, muscovite, molybdenite

Quartz, muscovite, molybdenite

$320 \mathrm{Ma}$

Nepheline, arfvedsonite, lepidomelane, molybdenite, aegirine, magnetite with titanium
$1248 \pm 25 \mathrm{Ma}$

$1248 \pm 25 \mathrm{Ma}$

$1248 \pm 25 \mathrm{Ma}$

$330-310 \mathrm{Ma}$

Archean

Archean 
Mo120c Moly Hill mine, La Motte, Abitibi, Canada

Archean

Mo121a Moly Hill mine, La Motte, Abitibi, Canada

Archean

Mo121b Moly Hill mine, La Motte, Abitibi, Canada

Archean

Mo121c Moly Hill mine, La Motte, Abitibi, Canada

Archean

Mo025 Toul-Porz, Côtes du Nord, France

Molybdenite, quartz, scheelite, wolframite, chalcopyrite, bismuthinite

$329 \pm 5 \mathrm{Ma}$

Mo028 Montbelleux-Luitré, Ile-et-Vilaine, France

Wolframite, molybdenite

$490 \pm 14 \mathrm{Ma}$

Perigran

itic

$374^{\circ} \mathrm{C}$ Mo029 Villeray Parcé, Ille-et-Villaine, France

Quartz, molybdenite

$490 \pm 14 \mathrm{Ma}$

Mo030 La Rousselière, Loire-Atlantique, France

Molybdenite, Bismuth

$320-290 \mathrm{Ma}$

Mo043 Tighza-Djebel Aouam, Morocco

Molybdenite, gold, scheelite

$286 \mathrm{Ma}$

Mo070 Salto do Lobo, Carris-Gerês, Portugal

$330-310 \mathrm{Ma}$

$<300^{\circ} \mathrm{C}$ Mo027 Menez Gouaillou, Coray, Finistère, France

Molybdenite, arsenopyrite, bismuthinite

$320 \mathrm{Ma}$

Greisen (Fersma

n) Mo042 Altenberg, Germany

$290-300 \mathrm{Ma}$

\begin{tabular}{|c|c|c|c|}
\hline Mo- & & $\begin{array}{l}\text { Mo- } \\
\text { Hend }\end{array}$ & Henderson mine, Colorado, USA \\
\hline $\begin{array}{c}\text { Porphyr } \\
\text { y } \\
\text { deposit }\end{array}$ & $\begin{array}{l}<400- \\
600^{\circ} \mathrm{C}\end{array}$ & $\begin{array}{l}\text { Mo- } \\
\text { Hend-b }\end{array}$ & Henderson mine, Colorado, USA \\
\hline
\end{tabular}

$27.66 \pm 10 \mathrm{Ma}$

$27.66 \pm 10 \mathrm{Ma}$

$27.66 \pm 10 \mathrm{Ma}$ 


\begin{tabular}{|c|c|c|c|c|}
\hline & & Mo081 & Climax, Colorado, USA & $33-24 \mathrm{Ma}$ \\
\hline & & Mo082 & Climax, Colorado, USA & $33-24 \mathrm{Ma}$ \\
\hline & & Mo054 & Tilly, Québec, Canada & $2745.8 \pm 0.8 \mathrm{Ma}$ \\
\hline & & Mo055 & Tilly, Québec, Canada & $2745.8 \pm 0.8 \mathrm{Ma}$ \\
\hline & & Mo056 & Questa, New Mexico, USA & $24 \mathrm{Ma}$ \\
\hline & & Mo057 & Questa, New Mexico, USA & $24 \mathrm{Ma}$ \\
\hline & & Mo079 & Questa, New Mexico, USA & $24 \mathrm{Ma}$ \\
\hline & & Mo080 & Questa, New Mexico, USA & $24 \mathrm{Ma}$ \\
\hline $\begin{array}{l}\text { Cu- } \\
\text { Porphyr }\end{array}$ & $<400-$ & Mo058 & Don-Rouyn, Abitibi, Canada & $2700 \mathrm{Ma}$ \\
\hline$y$ & $600^{\circ} \mathrm{C}$ & Mo059 & Don-Rouyn, Abitibi, Canada & $2700 \mathrm{Ma}$ \\
\hline & & Mo063 & Bingham Canyon, Utah, USA & $38.55 \pm 0.19 \mathrm{Ma}$ \\
\hline & & Mo071 & Chuquicamata, Chile & $39.5-37.5 \mathrm{Ma}$ \\
\hline & & Mo098 & $\begin{array}{l}\text { Tsagaan Suvarga, Omnogovi Province, } \\
\text { Mongolia }\end{array}$ & $240 \mathrm{Ma}$ \\
\hline & & Mo099 & $\begin{array}{l}\text { Tsagaan Suvarga, Omnogovi Province, } \\
\text { Mongolia }\end{array}$ & $240 \mathrm{Ma}$ \\
\hline & & Mo100 & Hashitu, China & $150 \pm 4 \mathrm{Ma}$ \\
\hline
\end{tabular}


Mo101 Hashitu, China

$150 \pm 4 \mathrm{Ma}$

Mo102 Hashitu, China

$150 \pm 4 \mathrm{Ma}$

Mo103 Hashitu, China

$150 \pm 4 \mathrm{Ma}$

Mo104 Hashitu, China

$150 \pm 4 \mathrm{Ma}$

Mo105 Hashitu, China

$150 \pm 4 \mathrm{Ma}$

Mo106 Hashitu, China

$150 \pm 4 \mathrm{Ma}$

Mo107 Hashitu, China

$150 \pm 4 \mathrm{Ma}$

Mo108 Hashitu, China

$150 \pm 4 \mathrm{Ma}$

Mo109 Thompson Creek, Idaho, USA

Mo110 Thompson Creek, Idaho, USA

Mo111 Butte, Montana, USA

$62.8 \mathrm{Ma}$

Mo112 Butte, Montana, USA

$62.8 \mathrm{Ma}$

Mo113 Butte, Montana, USA

$62.8 \mathrm{Ma}$

Mo114 Butte, Montana, USA

$62.8 \mathrm{Ma}$

Mo115 Butte, Montana, USA

$62.8 \mathrm{Ma}$

Mo116 Butte, Montana, USA

62.8 Ma

Mo117 Butte, Montana, USA

$62.8 \mathrm{Ma}$ 
Mo119 Butte, Montana, USA

Mo122 Sora, Russia

Mo123 Sora, Russia

Mo124 Sora, Russia

Mo125 Sora, Russia

Mo126 Zhireken, Eastern Transbaikalia, Russia

Mo127 Zhireken, Eastern Transbaikalia, Russia

Mo128 Zhireken, Eastern Transbaikalia, Russia

Mo129 Zhireken, Eastern Transbaikalia, Russia

Mo130 Zhireken, Eastern Transbaikalia, Russia

Mo131 Zhireken, Eastern Transbaikalia, Russia

Mo132 Zhireken, Eastern Transbaikalia, Russia

Mo133 Aksug, Russia

Mo134 Aksug, Russia

\begin{tabular}{|c|c|}
\hline & $62.8 \mathrm{Ma}$ \\
\hline Quartz-molybdenite vein & $405-388 \mathrm{Ma}$ \\
\hline Molybdenite nests in K-feldspar metasomatite & $405-388 \mathrm{Ma}$ \\
\hline Molybdenite dissemination in syenite & $405-388 \mathrm{Ma}$ \\
\hline $\begin{array}{l}\text { Molybdenite dissemination in quartz cement from breccia ore } \\
\text { zone }\end{array}$ & $405-388 \mathrm{Ma}$ \\
\hline Coarse-grained molybdenite in quartz vein & $160-155 \mathrm{Ma}$ \\
\hline Molybdenite dissemination in granite & $160-155 \mathrm{Ma}$ \\
\hline Molybdenite disseminated in quartz-K-feldspar metasomatite & $160-155 \mathrm{Ma}$ \\
\hline $\begin{array}{l}\text { Nests of molybdenite in altered fine-grained granites (argillic } \\
\text { alteration) }\end{array}$ & $160-155 \mathrm{Ma}$ \\
\hline Nests of molybdenite in potassically altered granites & $160-155 \mathrm{Ma}$ \\
\hline Quartz-molybdenite veinlets & $160-155 \mathrm{Ma}$ \\
\hline $\begin{array}{l}\text { Molydenite from breccia of argillized fine-grained granites } \\
\text { (molybdenite composing cement of this breccia) }\end{array}$ & $160-155 \mathrm{Ma}$ \\
\hline Molybdenite veinlet in tonalite & $404-401 \mathrm{Ma}$ \\
\hline n notacsica & $404-401 N$ \\
\hline
\end{tabular}


Mo135 Shaktama, Eastern Transbaikalia, Russia

Mo136 Shaktama, Eastern Transbaikalia, Russia

Mo137 Shaktama, Eastern Transbaikalia, Russia

Mo138 Erdenetuin Ovoo, Mongolia

Mo139 Erdenetiin Ovoo, Mongolia

Mo140 Erdenetiin Ovoo, Mongolia

Mo141 Bugdaya, Eastern Transbaikalia, Russia

Mo149 Bugdaya, Eastern Transbaikalia, Russia

Mo150 Bugdaya, Eastern Transbaikalia, Russia

Mo151 Bugdaya, Eastern Transbaikalia, Russia

Mo152 Bugdaya, Eastern Transbaikalia, Russia

Mo153 Bugdaya, Eastern Transbaikalia, Russia

Mo142 Davenda, Eastern Transbaikalia, Russia

Mo143 Davenda, Eastern Transbaikalia, Russia

Mo144 Davenda, Eastern Transbaikalia, Russia porphyry

Molybdenite veinlet in granite

$155-150 \mathrm{Ma}$

Molybdenite-pyrite vein in altered granite

$155-150 \mathrm{Ma}$

Quartz-molybdenite veinlet

$155-150 \mathrm{Ma}$

Quartz-molybdenite-pyrite veinlets in granodiorite porphyry

$240-220 \mathrm{Ma}$

Quartz-molybdenite veinlet

$240-220 \mathrm{Ma}$

Molybdenite from quartz-sericite metasomatite

$240-220 \mathrm{Ma}$

Molybdenite veinlet in altered quartz porphyry (quartz-albite alteration)

$154 \pm 3 \mathrm{Ma}$

$154 \pm 3 \mathrm{Ma}$

$154 \pm 3 \mathrm{Ma}$

$154 \pm 3 \mathrm{Ma}$

$154 \pm 3 \mathrm{Ma}$

$154 \pm 3 \mathrm{Ma}$

Quartz-molybdenite vein

Mesozoic

Quartz-molybdenite veinlet in aplite-like granite

Mesozoic

Quartz-molybdenite veinlet in potassically altered granite

Mesozoic 
Mo145 Chubachi, Russia

Mo146 Veseloye, Russia

Mo147 Okonon, Russia

Mo148 Vykhodnoye, Russia

Mo154 Dasuji-Zhuozi county, Inner Mongolia, China

Mo155

Caosiyao-Xinghe county, Inner Mongolia,

China

Mo156

Caosiyao-Xinghe county, Inner Mongolia,

China

Mo157

Caosiyao-Xinghe county, Inner Mongolia,

China

Caosiyao-Xinghe county, Inner Mongolia,

Mo158

China

Mo159 Caosiyao-Xinghe county, Inner Mongolia,

China

Mo160 Caosiyao-Xinghe county, Inner Mongolia,

China

Mo161 Caosiyao-Xinghe county, Inner Mongolia,

China

Mo162 Ulandler-Sunid Zuoqi area, Inner Mongolia,
Quartz-molybdenite veinlet in granodiorite porphyry

$130 \mathrm{Ma}$

Quartz-molybdenite-pyrite vein in granite

Quartz-molybdenite-pyrite veinlet in granodiorite porphyry

Quartz-molybdenite veinlet in granodiorite porphyry

$110-105 \mathrm{Ma}$

$120-140 \mathrm{Ma}$

$120-140 \mathrm{Ma}$

120 - $140 \mathrm{Ma}$

120 - $140 \mathrm{Ma}$

120 - $140 \mathrm{Ma}$

120 - $140 \mathrm{Ma}$

120 - $140 \mathrm{Ma}$

120 - $140 \mathrm{Ma}$

120 - $140 \mathrm{Ma}$ 


\section{China}

Mo163

Ulandler-Sunid Zuoqi area, Inner Mongolia, China

Mo164 Ulandler-Sunid Zuoqi area, Inner Mongolia, China

$120-140 \mathrm{Ma}$

Mo165 Ulandler-Sunid Zuoqi area, Inner Mongolia, China

120 - $140 \mathrm{Ma}$

Mo166 Ulandler-Sunid Zuoqi area, Inner Mongolia, China

120 - $140 \mathrm{Ma}$

Mo172 Donggebi, Tianshan, China

$235 \mathrm{Ma}$

Mo173 Dongchuan, Yunnan, China

Mo174 Linxi, Inner Mongolia, China

Mo175 Linxi, Inner Mongolia, China molybdenite, and quartz vein

Molybdenite-mineralized albitite, disseminate

Dark gray silty tuffaceous slate with molybdenite veinlet and quartz vein

Hoar altered rocks with molybdenite veinlet, disseminated

\section{1 - $1.2 \mathrm{Ga}$}

120 - $140 \mathrm{Ma}$

120 - $140 \mathrm{Ma}$

$235 \mathrm{Ma}$

$235 \mathrm{Ma}$

$235 \mathrm{Ma}$

$235 \mathrm{Ma}$ 
Mo004 Azegour, Morocco

Mo007 Azegour, Morocco

Mo008 Azegour, Morocco

Mo072 Azegour, Morocco

Mo073 Azegour, Morocco

Mo074a Azegour, Morocco

Mo074b Azegour, Morocco

200- Mo074c Azegour, Morocco $1200^{\circ} \mathrm{C}$

Skarn (Wallma Mo075a Azegour, Morocco ch et al.,

1989) Mo075b Azegour, Morocco

Mo076a Azegour, Morocco

Mo076b Azegour, Morocco

Mo077 Azegour, Morocco

Mo078 Azegour, Morocco

Mo084a Azegour, Morocco

Mo084b Azegour, Morocco

Mo084c Azegour, Morocco
Coarse molybdenite in grenatite, few micrograins of chalcopyrite $271 \pm 3 \mathrm{Ma}$

Coarse molybdenite in grenatite, few micrograins of chalcopyrite $271 \pm 3 \mathrm{Ma}$ (2)

Coarse molybdenite in grenatite, few micrograins of chalcopyrite $271 \pm 3 \mathrm{Ma}$ $r$ r

Coarse molybdenite in grenatite, few micrograins of chalcopyrite $271 \pm 3 \mathrm{Ma}$ Coarse molybdenite in grenatite, few micrograins of chalcopyrite $271 \pm 3 \mathrm{Ma}$ Coarse molybdenite in grenatite, few micrograins of chalcopyrite $271 \pm 3 \mathrm{Ma}$ ras

Coarse molybdenite in grenatite, few micrograins of chalcopyrite $271 \pm 3 \mathrm{Ma}$ Coarse

Coarse molybdenite in grenatite, few micrograins of chalcopyrite $271 \pm 3 \mathrm{Ma}$

Coarse molybdenite in grenatite, few micrograins of chalcopyrite $271 \pm 3 \mathrm{Ma}$

Coarse molybdenite in grenatite, few micrograins of chalcopyrite $271 \pm 3 \mathrm{Ma}$

Coarse molybdenite in grenatite, few micrograins of chalcopyrite $271 \pm 3 \mathrm{Ma}$

Coarse molybdenite in grenatite, few micrograins of chalcopyrite $271 \pm 3 \mathrm{Ma}$

Dissiminate molybdenite in grenatite

$271 \pm 3 \mathrm{Ma}$

Dissiminate molybdenite in grenatite

$271 \pm 3 \mathrm{Ma}$

Coarse molybdenite in grenatite, few micrograins of chalcopyrite $271 \pm 3 \mathrm{Ma}$

Coarse molybdenite in grenatite, few micrograins of chalcopyrite $271 \pm 3 \mathrm{Ma}$

Coarse molybdenite in grenatite, few micrograins of chalcopyrite $271 \pm 3 \mathrm{Ma}$ 
Mo085a Azegour, Morocco

Mo085b Azegour, Morocco

Mo085c Azegour, Morocco

Mo085d Azegour, Morocco

Mo086a Azegour, Morocco

Mo086b Azegour, Morocco

Mo087 Azegour, Morocco

Mo088a Azegour, Morocco

Mo088b Azegour, Morocco

Mo089a Azegour, Morocco

Mo089b Azegour, Morocco

Mo090 Azegour, Morocco

Mo035 Dielette-Flamanville, Manche, France

Mo036 Dielette-Flamanville, Manche, France

Mo040 Isk Imoula, Tichka, Morocco

Mo041 Ikissane, Tichka, Morocco

Mo083 Edwards, New York, USA
Coarse molybdenite in grenatite, few micrograins of chalcopyrite $271 \pm 3 \mathrm{Ma}$

Coarse molybdenite in grenatite, few micrograins of chalcopyrite $271 \pm 3 \mathrm{Ma}$ (1)

Coarse molybdenite in grenatite, few micrograins of chalcopyrite $271 \pm 3 \mathrm{Ma}$

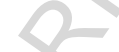

Coarse molybdenite in grenatite, few micrograins of chalcopyrite $271 \pm 3 \mathrm{Ma}$ Coarse molybdenite in grenatite, few micrograins of chalcopyrite $271 \pm 3 \mathrm{Ma}$ Coarse molybdenite in grenatite, few micrograins of chalcopyrite $271 \pm 3 \mathrm{Ma}$ r

Coarse molybdenite in grenatite, few micrograins of chalcopyrite $271 \pm 3 \mathrm{Ma}$ Coarse

Coarse molybdenite in grenatite, few micrograins of chalcopyrite $271 \pm 3 \mathrm{Ma}$

Coarse molybdenite in grenatite, few micrograins of chalcopyrite $271 \pm 3 \mathrm{Ma}$

Coarse molybdenite in grenatite, few micrograins of chalcopyrite $271 \pm 3 \mathrm{Ma}$

Coarse molybdenite in grenatite, few micrograins of chalcopyrite $271 \pm 3 \mathrm{Ma}$

Coarse molybdenite in grenatite, few micrograins of chalcopyrite $271 \pm 3 \mathrm{Ma}$

$320 \mathrm{Ma}$

$320 \mathrm{Ma}$

Late hercynian

Molybdenite, copper

Late hercynian

$1100 \mathrm{Ma}$ 
Mo013 La Meije, Hautes Alpes, France

$23-5 \mathrm{Ma}$

Mo014 Combe Laurichard, Hautes Alpes, France

$23-5 \mathrm{Ma}$

Mo015 Glacier de l'homme, Hautes Alpes, France

$23-5 \mathrm{Ma}$

Mo016 Clos I'Oureou, Hautes Alpes, France

$23-5 \mathrm{Ma}$

Mo017 Clos l'Oureou, Hautes Alpes, France

$23-5 \mathrm{Ma}$

Mo018 Glacier de Bonne Pierre, Isère, France

$23-5 \mathrm{Ma}$

$23-5 \mathrm{Ma}$

Alpine-

Mo019 Glacier de Bonne Pierre, Isère, France

$23-5 \mathrm{Ma}$

fissure $<300^{\circ} \mathrm{C}$ Mo020 Glacier de Bonne Pierre, Isère, France

veins

Mo021 Ravin de la Ruine, Isère, France

$23-5 \mathrm{Ma}$

Mo022 Ravin de la Ruine, Isère, France

$23-5 \mathrm{Ma}$

Mo023 Ravin de la Ruine, Isère, France

$23-5 \mathrm{Ma}$

Mo024 Tête du Rouget, Isère, France

$23-5 \mathrm{Ma}$

Mo037 Baltschiedertal, Switzerland

$23-5 \mathrm{Ma}$

Mo038 Baltschiedertal, Switzerland

$23-5 \mathrm{Ma}$

Mo060 Stilluptal, Zillertal, Austria

Albite, chlorite, muscovite, quartz, molybdenite

$23-5 \mathrm{Ma}$

160-

IOCG $\quad 800^{\circ} \mathrm{C}$ Mo091 Lala, China

$1086 \pm 8 \mathrm{Ma}$

(Chen, 
2008)

Mo003 Spain
Mo005 Morocco
Mo006 Québec, Canada
Unknow
Mo044 Cameroon
Mo068 Borralha, Portugal
Mo092 Sunderbyn, Luleå area, Sweden
Mo093 Sunderbyn, Luleå area, Sweden


Table 2

\begin{tabular}{|c|c|c|c|c|c|c|c|}
\hline Occurrence type & ID & Location & $\mathrm{n}$ & $\frac{\delta^{97} \mathrm{Mo}_{\text {NIST }}}{}$ & $2 \sigma$ & $\overline{\delta^{98} \mathrm{Mo}_{\text {NIST }}}$ & $2 \sigma$ \\
\hline \multirow{14}{*}{ Granite } & Mo001 & Kigom, Nigeria & 6 & -0.22 & 0.04 & -0.32 & 0.06 \\
\hline & Mo031 & Becon les granits, Maine-et-Loire, France & 5 & -0.28 & 0.08 & -0.4 & 0.06 \\
\hline & Mo032 & Becon les granits, Maine-et-Loire, & 10 & -0.48 & 0.06 & -0.71 & 0.07 \\
\hline & Mo033 & Becon les granits, Maine-et-Loire, France & 8 & -0.23 & 0.04 & -0.34 & 0.05 \\
\hline & Mo034 & Becon les granits, Maine-et-Loire, France & 8 & -0.01 & 0.04 & -0.02 & 0.05 \\
\hline & Mo053 & Becon les granits, Maine-et-Loire, France & 5 & -0.3 & 0.03 & -0.48 & 0.1 \\
\hline & Mo039 & Man Departement, Ivory Coast & 8 & -0.19 & 0.04 & -0.26 & 0.09 \\
\hline & Mo046 & Bamiyan valley, Afghanistan & 5 & 0.38 & 0.06 & 0.55 & 0.09 \\
\hline & Mo047 & Traouiéros, Côtes d'Armor, France & 5 & -0.44 & 0.04 & -0.68 & 0.08 \\
\hline & Mo167 & Wurinitu, Inner Mongolia, China & 4 & -0.19 & 0.06 & -0.29 & 0.06 \\
\hline & Mo168 & Wurinitu, Inner Mongolia, China & 4 & -0.19 & 0.03 & -0.31 & 0.07 \\
\hline & Mo169 & Wurinitu, Inner Mongolia, China & 4 & -0.21 & 0.07 & -0.32 & 0.08 \\
\hline & Mo170 & Wurinitu, Inner Mongolia, China & 5 & -0.08 & 0.03 & -0.11 & 0.05 \\
\hline & Mo171 & Wurinitu, Inner Mongolia, China & 5 & -0.19 & 0.07 & -0.28 & 0.07 \\
\hline Pegmatite & Mo002 & Thornborough Hodgkinson Gold Field, Queensland, Australia & 6 & -0.08 & 0.06 & -0.13 & 0.12 \\
\hline
\end{tabular}




$\begin{array}{ll}\text { Mo009a } & \text { Preissac, Abitibi, Canada } \\ \text { Mo009b } & \text { Preissac, Abitibi, Canada } \\ \text { Mo010 } & \text { Château-Lambert, Vosges, France } \\ \text { Mo012 } & \text { La clarté Ploumanac'h, Côtes d'Armor, France } \\ \text { Mo026 } & \text { La clarté Ploumanac'h, Côtes d'Armor, France } \\ \text { Mo061 } & \text { La clarté Ploumanac'h, Côtes d'Armor, France } \\ \text { Mo062 } & \text { La clarté Ploumanac'h, Côtes d'Armor, France } \\ \text { Mo064 } & \text { La clarté Ploumanac'h, Côtes d'Armor, France } \\ \text { Mo065 } & \text { La clarté Ploumanac'h, Côtes d'Armor, France } \\ \text { Mo066 } & \text { La clarté Ploumanac'h, Côtes d'Armor, France } \\ \text { Mo067 } & \text { La clarté Ploumanac'h, Côtes d'Armor, France } \\ \text { Mo045 } & \text { Nunavik, Québec, Canada } \\ \text { Mo048 } & \text { Menez Goaillou, France } \\ \text { Mo049 } & \text { Läven, Norway } \\ \text { Mo050 } & \text { Ivigtut, Arsuk, Greenland } \\ \text { Mo051 } & \text { Ivigtut, Arsuk, Greenland } \\ \text { Mo052 } & \text { Ivigtut, Arsuk, Greenland }\end{array}$

\begin{tabular}{lllll}
6 & -0.16 & 0.05 & -0.24 & 0.07 \\
5 & -0.41 & 0.03 & -0.61 & 0.06 \\
9 & 0.77 & 0.08 & 1.14 & 0.12 \\
5 & -0.31 & 0.06 & -0.46 & 0.08 \\
8 & -0.39 & 0.08 & -0.58 & 0.12 \\
9 & -0.42 & 0.05 & -0.61 & 0.09 \\
9 & -0.35 & 0.1 & -0.52 & 0.15 \\
5 & -0.43 & 0.06 & -0.68 & 0.12 \\
5 & -0.31 & 0.05 & -0.48 & 0.06 \\
5 & -0.39 & 0.08 & -0.61 & 0.09 \\
\hline 5 & -0.32 & 0.06 & -0.54 & 0.12 \\
5 & -0.14 & 0.06 & -0.23 & 0.13 \\
\hline 10 & -0.04 & 0.07 & -0.04 & 0.09 \\
6 & -0.42 & 0.05 & -0.6 & 0.09 \\
6 & 0.45 & 0.07 & 0.7 & 0.11 \\
6 & 0.39 & 0.04 & 0.6 & 0.1 \\
5 & 0.16 & 0.07 & 0.26 & 0.09
\end{tabular}




\begin{tabular}{|c|c|c|c|c|c|c|c|}
\hline & Mo069 & Cubos e Chao do Castanheiro, Mangualde, Portugal & 7 & 0.34 & 0.06 & 0.51 & 0.13 \\
\hline & Mo094 & Sunderbyn, Luleå area, Sweden & 6 & 0.54 & 0.04 & 0.8 & 0.06 \\
\hline & Mo095 & Sunderbyn, Luleå area, Sweden & 5 & -0.11 & 0.02 & -0.15 & 0.04 \\
\hline & Mo096 & Sunderbyn, Luleå area, Sweden & 10 & 0.27 & 0.07 & 0.41 & 0.08 \\
\hline & Mo097 & Sunderbyn, Luleå area, Sweden & 4 & 0.57 & 0.03 & 0.85 & 0.05 \\
\hline & Mo120a & Moly Hill mine, La Motte, Abitibi, Canada & 4 & -0.2 & 0.02 & -0.3 & 0.04 \\
\hline & Mo120b & Moly Hill mine, La Motte, Abitibi, Canada & 4 & -0.32 & 0.04 & -0.47 & 0.06 \\
\hline & Mo120c & Moly Hill mine, La Motte, Abitibi, Canada & 4 & -0.11 & 0.03 & -0.17 & 0.02 \\
\hline & Mo121a & Moly Hill mine, La Motte, Abitibi, Canada & 4 & -0.32 & 0.06 & -0.46 & 0.05 \\
\hline & Mo121b & Moly Hill mine, La Motte, Abitibi, Canada & 4 & -0.16 & 0.03 & -0.25 & 0.04 \\
\hline & Mo121c & Moly Hill mine, La Motte, Abitibi, Canada & 4 & -0.32 & 0.05 & -0.47 & 0.06 \\
\hline & Mo025 & Toul-Porz, Côtes du Nord, France & 4 & 0.74 & 0.07 & 1.09 & 0.09 \\
\hline & Mo028 & Montbelleux-Luitré, Ile-et-Vilaine, France & 5 & 0.01 & 0.07 & 0.02 & 0.12 \\
\hline & Mo029 & Villeray Parcé, Ille-et-Villaine, France & 5 & 0.02 & 0.07 & 0.01 & 0.11 \\
\hline & Mo030 & La Rousselière, Loire-Atlantique, France & 13 & 0.42 & 0.09 & 0.62 & 0.13 \\
\hline & Mo043 & Tighza-Djebel Aouam, Morocco & 5 & 0.57 & 0.03 & 0.79 & 0.04 \\
\hline & Mo070 & Salto do Lobo, Carris-Gerês, Portugal & 9 & 0.41 & 0.08 & 0.62 & 0.11 \\
\hline
\end{tabular}




\begin{tabular}{|c|c|c|c|c|c|c|c|}
\hline \multirow{3}{*}{ Greisen } & \\
\hline & Mo027 & Menez Gouaillou, Coray, Finistère, France & 5 & -0.22 & 0.11 & -0.35 & 0.11 \\
\hline & Mo042 & Altenberg, Germany & 5 & 0.74 & 0.07 & 1.07 & 0.09 \\
\hline \multirow{5}{*}{ Mo-Porphyry deposit } & Mo-Hend & Henderson mine, Colorado, USA & 47 & -0.13 & 0.06 & -0.19 & 0.09 \\
\hline & Mo-Hend-b & Henderson mine, Colorado, USA & 6 & -0.15 & 0.06 & -0.22 & 0.1 \\
\hline & Mo011 & Henderson mine, Colorado, USA & 5 & -0.4 & 0.04 & -0.6 & 0.06 \\
\hline & Mo081 & Climax, Colorado, USA & 9 & -0.35 & 0.07 & -0.52 & 0.11 \\
\hline & Mo082 & Climax, Colorado, USA & 8 & -0.1 & 0.07 & -0.14 & 0.09 \\
\hline \multirow{10}{*}{ Cu-Porphyry deposit } & Mo054 & Tilly, Québec, Canada & 8 & -0.58 & 0.09 & -0.86 & 0.13 \\
\hline & Mo055 & Tilly, Québec, Canada & 5 & -0.2 & 0.08 & -0.28 & 0.1 \\
\hline & Mo056 & Questa, New Mexico, USA & 8 & -0.29 & 0.09 & -0.43 & 0.12 \\
\hline & Mo057 & Questa, New Mexico, USA & 10 & -0.19 & 0.08 & -0.27 & 0.1 \\
\hline & Mo079 & Questa, New Mexico, USA & 7 & -0.39 & 0.05 & -0.57 & 0.09 \\
\hline & Mo080 & Questa, New Mexico, USA & 8 & -0.38 & 0.09 & -0.56 & 0.12 \\
\hline & Mo058 & Don-Rouyn, Abitibi, Canada & 6 & 0.15 & 0.05 & 0.21 & 0.11 \\
\hline & Mo059 & Don-Rouyn, Abitibi, Canada & 6 & 0.08 & 0.07 & 0.12 & 0.07 \\
\hline & Mo063 & Bingham Canyon, Utah, USA & 8 & -0.39 & 0.11 & -0.58 & 0.13 \\
\hline & Mo071 & Chuquicamata, Chile & 7 & -0.11 & 0.06 & -0.15 & 0.12 \\
\hline
\end{tabular}




\begin{tabular}{ll} 
Mo098 & Tsagaan Suvarga, Omnogovi Province, Mongolia \\
Mo099 & Tsagaan Suvarga, Omnogovi Province, Mongolia \\
Mo100 & Hashitu, China \\
Mo101 & Hashitu, China \\
Mo102 & Hashitu, China \\
Mo103 & Hashitu, China \\
Mo104 & Hashitu, China \\
Mo105 & Hashitu, China \\
Mo106 & Hashitu, China \\
Mo107 & Hashitu, China \\
Mo108 & Hashitu, China \\
Mo109 & Thompson Creek, Idaho, USA \\
Mo110 & Thompson Creek, Idaho, USA \\
Mo111 & Butte, Montana, USA \\
Mo112 & Butte, Montana, USA \\
Mo113 & Butte, Montana, USA \\
Mo114 & Butte, Montana, USA \\
\hline
\end{tabular}

\begin{tabular}{ccccc}
4 & -0.43 & 0.04 & -0.63 & 0.03 \\
4 & -0.59 & 0.06 & -0.86 & 0.06 \\
5 & 0.13 & 0.05 & 0.2 & 0.09 \\
4 & 0.17 & 0.08 & 0.26 & 0.13 \\
4 & 0.19 & 0.03 & 0.27 & 0.02 \\
4 & 0.17 & 0.07 & 0.25 & 0.07 \\
4 & 0 & 0.06 & 0 & 0.06 \\
4 & 0.16 & 0.04 & 0.24 & 0.04 \\
\hline 3 & 0.12 & 0.06 & 0.18 & 0.11 \\
\hline 3 & 0.26 & 0.05 & 0.37 & 0.03 \\
\hline 4 & 0.07 & 0.07 & 0.1 & 0.11 \\
\hline 4 & -0.11 & 0.05 & -0.18 & 0.07 \\
\hline 4 & -0.12 & 0.08 & -0.16 & 0.11 \\
\hline 4 & -0.31 & 0.03 & -0.44 & 0.05 \\
4 & -0.23 & 0.04 & -0.33 & 0.05 \\
4 & 0.01 & 0.02 & 0.01 & 0.04 \\
6 & -0.3 & 0.06 & -0.44 & 0.1 \\
\hline
\end{tabular}




\begin{tabular}{|c|c|c|c|c|c|c|}
\hline Mo115 & Butte, Montana, USA & 4 & 0.03 & 0.08 & 0.04 & 0.06 \\
\hline Mo116 & Butte, Montana, USA & 4 & -0.25 & 0.04 & -0.38 & 0.09 \\
\hline Mo117 & Butte, Montana, USA & 6 & -0.27 & 0.04 & -0.4 & 0.06 \\
\hline Mo118 & Butte, Montana, USA & 4 & -0.24 & 0.03 & -0.36 & 0.07 \\
\hline Mo119 & Butte, Montana, USA & 3 & -0.37 & 0.06 & -0.54 & 0.09 \\
\hline Mo122 & Sora, Russia & 4 & -0.37 & 0.07 & -0.55 & 0.09 \\
\hline Mo123 & Sora, Russia & 4 & -0.34 & 0.02 & -0.51 & 0.07 \\
\hline Mo124 & Sora, Russia & 4 & -0.35 & 0.06 & -0.52 & 0.08 \\
\hline Mo125 & Sora, Russia & 4 & -0.42 & 0.01 & -0.6 & 0.02 \\
\hline Mo126 & Zhireken, Eastern Transbaikalia, Russia & 4 & -0.18 & 0.07 & -0.26 & 0.12 \\
\hline Mo127 & Zhireken, Eastern Transbaikalia, Russia & 4 & -0.28 & 0.07 & -0.41 & 0.08 \\
\hline Mo128 & Zhireken, Eastern Transbaikalia, Russia & 4 & -0.12 & 0.09 & -0.16 & 0.13 \\
\hline Mo129 & Zhireken, Eastern Transbaikalia, Russia & 4 & -0.15 & 0.02 & -0.21 & 0.05 \\
\hline Mo130 & Zhireken, Eastern Transbaikalia, Russia & 4 & -0.15 & 0.04 & -0.25 & 0.08 \\
\hline Mo131 & Zhireken, Eastern Transbaikalia, Russia & 4 & -0.05 & 0.06 & -0.09 & 0.05 \\
\hline Mo132 & Zhireken, Eastern Transbaikalia, Russia & 4 & -0.25 & 0.04 & -0.36 & 0.06 \\
\hline Mo133 & Aksug, Russia & 4 & -0.28 & 0.03 & -0.41 & 0.0 \\
\hline
\end{tabular}




$\begin{array}{ll}\text { Mo134 } & \text { Aksug, Russia } \\ \text { Mo135 } & \text { Shaktama, Eastern Transbaikalia, Russia } \\ \text { Mo136 } & \text { Shaktama, Eastern Transbaikalia, Russia } \\ \text { Mo137 } & \text { Shaktama, Eastern Transbaikalia, Russia } \\ \text { Mo138 } & \text { Erdenetuin Ovoo, Mongolia } \\ \text { Mo139 } & \text { Erdenetiin Ovoo, Mongolia } \\ \text { Mo140 } & \text { Erdenetiin Ovoo, Mongolia } \\ \text { Mo141 } & \text { Bugdaya, Eastern Transbaikalia, Russia } \\ \text { Mo149 } & \text { Bugdaya, Eastern Transbaikalia, Russia } \\ \text { Mo150 } & \text { Bugdaya, Eastern Transbaikalia, Russia } \\ \text { Mo151 } & \text { Bugdaya, Eastern Transbaikalia, Russia } \\ \text { Mo152 } & \text { Bugdaya, Eastern Transbaikalia, Russia } \\ \text { Mo153 } & \text { Bugdaya, Eastern Transbaikalia, Russia } \\ \text { Mo142 } & \text { Davenda, Eastern Transbaikalia, Russia } \\ \text { Mo143 } & \text { Davenda, Eastern Transbaikalia, Russia } \\ \text { Mo144 } & \text { Davenda, Eastern Transbaikalia, Russia } \\ \text { Mo145 } & \text { Chubachi, Russia }\end{array}$

\begin{tabular}{lllll}
6 & -0.09 & 0.07 & -0.13 & 0.13 \\
4 & -0.35 & 0.04 & -0.52 & 0.07 \\
4 & -0.26 & 0.04 & -0.39 & 0.05 \\
4 & -0.38 & 0.05 & -0.57 & 0.08 \\
4 & -0.39 & 0.04 & -0.58 & 0.02 \\
\hline 4 & -0.26 & 0.06 & -0.39 & 0.11 \\
\hline 4 & -0.33 & 0.06 & -0.49 & 0.15 \\
\hline 4 & -0.13 & 0.06 & -0.19 & 0.07 \\
\hline 4 & 0.06 & 0.07 & 0.08 & 0.11 \\
\hline 4 & -0.3 & 0.09 & -0.46 & 0.07 \\
\hline 4 & -0.07 & 0.03 & -0.12 & 0.05 \\
\hline 4 & -0.65 & 0.04 & -0.97 & 0.09 \\
\hline 4 & 0.25 & 0.07 & 0.36 & 0.07 \\
\hline 4 & -0.23 & 0.02 & -0.33 & 0.07 \\
\hline 4 & 0.22 & 0.04 & 0.33 & 0.05 \\
\hline 4 & -0.05 & 0.07 & -0.09 & 0.1 \\
\hline 4 & -0.57 & 0.02 & -0.85 & 0.05
\end{tabular}




$\begin{array}{lllllll}\text { Mo146 } & \text { Veseloye, Russia } & 4 & -0.38 & 0.04 & -0.56 & 0.03 \\ \text { Mo147 } & \text { Okonon, Russia } & 4 & -0.27 & 0.06 & -0.42 & 0.04 \\ \text { Mo148 } & \text { Vykhodnoye, Russia } & 4 & 0.03 & 0.04 & 0.04 & 0.07 \\ \text { Mo154 } & \text { Dasuji-Zhuozi county, Inner Mongolia, China } & 4 & 0.14 & 0.07 & 0.21 & 0.12 \\ \text { Mo155 } & \text { Caosiyao-Xinghe county, Inner Mongolia, China } & 4 & -0.11 & 0.02 & -0.16 & 0.04 \\ \text { Mo156 } & \text { Caosiyao-Xinghe county, Inner Mongolia, China } & 4 & -0.1 & 0.06 & -0.14 & 0.08 \\ \text { Mo157 } & \text { Caosiyao-Xinghe county, Inner Mongolia, China } & 4 & -0.08 & 0.08 & -0.11 & 0.1 \\ \text { Mo158 } & \text { Caosiyao-Xinghe county, Inner Mongolia, China } & 4 & -0.09 & 0.08 & -0.13 & 0.07 \\ \text { Mo159 } & \text { Caosiyao-Xinghe county, Inner Mongolia, China } & 4 & -0.11 & 0.06 & -0.17 & 0.1 \\ \text { Mo160 } & \text { Caosiyao-Xinghe county, Inner Mongolia, China } & 4 & -0.51 & 0.02 & -0.76 & 0.03 \\ \text { Mo161 } & \text { Caosiyao-Xinghe county, Inner Mongolia, China } & 4 & -0.47 & 0.03 & -0.7 & 0.06 \\ \text { Mo162 } & \text { Ulandler-Sunid Zuoqi area, Inner Mongolia, China } & 4 & -0.04 & 0.07 & -0.07 & 0.1 \\ \text { Mo163 } & \text { Ulandler-Sunid Zuoqi area, Inner Mongolia, China } & 4 & -0.05 & 0.05 & -0.07 & 0.06 \\ \text { Mo164 } & \text { Ulandler-Sunid Zuoqi area, Inner Mongolia, China } & 4 & -0.04 & 0.02 & -0.07 & 0.06 \\ \text { Mo165 } & \text { Ulandler-Sunid Zuoqi area, Inner Mongolia, China } & 4 & -0.06 & 0.02 & -0.09 & 0.01 \\ \text { Mo166 } & \text { Ulandler-Sunid Zuoqi area, Inner Mongolia, China } & 4 & -0.03 & 0.02 & -0.04 & 0.03 \\ \text { Mo172 } & \text { Donggebi, Tianshan, China } & -5 & 0.09 & 0.06 & 0.14 & 0.07\end{array}$




\begin{tabular}{|c|c|c|c|c|c|c|c|}
\hline & Mo173 & Dongchuan, Yunnan, China & 5 & 0.57 & 0.02 & 0.84 & 0.05 \\
\hline & Mo174 & Linxi, Inner Mongolia, China & 5 & -0.19 & 0.02 & -0.28 & 0.01 \\
\hline & Mo175 & Linxi, Inner Mongolia, China & 5 & -0.13 & 0.03 & -0.19 & 0.04 \\
\hline & Mo176 & Donggebi, Tianshan, China & 5 & -0.32 & 0.05 & -0.47 & 0.09 \\
\hline & Mo177 & Donggebi, Tianshan, China & 5 & -0.21 & 0.02 & -0.32 & 0.05 \\
\hline & Mo178 & Donggebi, Tianshan, China & 5 & 0.18 & 0.03 & 0.27 & 0.04 \\
\hline & Mo179 & Donggebi, Tianshan, China & 5 & -0.4 & 0.03 & -0.59 & 0.07 \\
\hline & Mo004 & Azegour, Morocco & 6 & 0.05 & 0.09 & 0.07 & 0.11 \\
\hline & Mo007 & Azegour, Morocco & 6 & -0.29 & 0.08 & -0.43 & 0.09 \\
\hline & Mo008 & Azegour, Morocc & 6 & 0.21 & 0.05 & 0.32 & 0.09 \\
\hline & Mo072 & Azegour, Morocco & 5 & -0.35 & 0.06 & -0.55 & 0.1 \\
\hline & Mo073 & Azegour, Morocco & 6 & -0.4 & 0.09 & -0.6 & 0.12 \\
\hline & Mo074a & Azegour, Morocco & 5 & 0.21 & 0.07 & 0.25 & 0.12 \\
\hline & Mo074b & Azegour, Morocco & 5 & -0.08 & 0.03 & -0.17 & 0.09 \\
\hline & Mo074c & Azegour, Morocco & 6 & -0.02 & 0.05 & -0.08 & 0.06 \\
\hline & Mo075a & Azegour, Morocco & 6 & 0.13 & 0.09 & 0.16 & 0.2 \\
\hline & Mo075b & Azegour, Morocco & 6 & 0.23 & 0.07 & 0.29 & 0.1 \\
\hline
\end{tabular}




\begin{tabular}{ll} 
Mo076a & Azegour, Morocco \\
Mo076b & Azegour, Morocco \\
Mo077 & Azegour, Morocco \\
Mo078 & Azegour, Morocco \\
Mo084a & Azegour, Morocco \\
Mo084b & Azegour, Morocco \\
Mo084c & Azegour, Morocco \\
Mo085a & Azegour, Morocco \\
Mo085b & Azegour, Morocco \\
Mo085c & Azegour, Morocco \\
Mo085d & Azegour, Morocco \\
\hline Mo086a & Azegour, Morocco \\
\hline Mo086b & Azegour, Morocco \\
\hline Mo087 & Azegour, Morocco \\
Mo088a & Azegour, Morocco \\
Mo088b & Azegour, Morocco \\
Mo089a & Azegour, Morocco
\end{tabular}

\begin{tabular}{|c|c|c|c|c|}
\hline 6 & -0.08 & 0.07 & -0.17 & 0.11 \\
\hline 6 & 0.32 & 0.07 & 0.42 & 0.13 \\
\hline 6 & 0.3 & 0.07 & 0.4 & 0.13 \\
\hline 6 & 0.08 & 0.1 & 0.08 & 0.19 \\
\hline 5 & -0.18 & 0.04 & -0.26 & 0.08 \\
\hline 5 & -0.09 & 0.02 & -0.14 & 0.05 \\
\hline 5 & -0.2 & 0.02 & -0.31 & 0.02 \\
\hline 5 & -0.09 & 0.09 & -0.13 & 0.1 \\
\hline 5 & 0.02 & 0.08 & 0.04 & 0.08 \\
\hline 5 & -0.14 & 0.04 & -0.17 & 0.05 \\
\hline 5 & -0.08 & 0.03 & -0.1 & 0.04 \\
\hline 8 & -0.13 & 0.09 & -0.19 & 0.14 \\
\hline 5 & -0.18 & 0.07 & -0.27 & 0.12 \\
\hline 5 & 0.18 & 0.06 & 0.26 & 0.11 \\
\hline 5 & 0.03 & 0.05 & 0.04 & 0.04 \\
\hline 5 & 0.17 & 0.07 & 0.25 & 0.1 \\
\hline & 0.03 & 0.07 & 0.04 & \\
\hline
\end{tabular}




\begin{tabular}{|c|c|c|c|c|c|c|c|}
\hline & Mo089b & Azegour, Morocco & 5 & 0.27 & 0.04 & 0.41 & 0.06 \\
\hline & Mo090 & Azegour, Morocco & 5 & 0.11 & 0.04 & 0.18 & 0.08 \\
\hline & Mo035 & Dielette-Flamanville, Manche, France & 5 & 0 & 0.08 & 0.01 & 0.13 \\
\hline & Mo036 & Dielette-Flamanville, Manche, France & 10 & -0.08 & 0.1 & -0.11 & 0.13 \\
\hline & Mo040 & Isk Imoula, Tichka, Morocco & 8 & 0.09 & 0.04 & 0.14 & 0.07 \\
\hline & Mo041 & Ikissane, Tichka, Morocco & 6 & 0.51 & 0.08 & 0.75 & 0.12 \\
\hline & Mo083 & Edwards, New York, USA & 6 & 0.1 & 0.07 & 0.15 & 0.1 \\
\hline \multirow{10}{*}{ Alpine-type fissure veins } & Mo013 & La Meije, Hautes Alpes, France & 6 & 0.31 & 0.06 & 0.45 & 0.07 \\
\hline & Mo014 & Combe Laurichard, Hautes Alpes, France & 5 & 0.06 & 0.09 & 0.08 & 0.07 \\
\hline & Mo015 & Glacier de I'homme, Hautes Alpes, France & 5 & 0.89 & 0.09 & 1.31 & 0.11 \\
\hline & Mo016 & Clos I'Oureou, Hautes Alpes, France & 6 & -0.05 & 0.07 & -0.06 & 0.08 \\
\hline & Mo017 & Clos I'Oureou, Hautes Alpes, France & 6 & -0.07 & 0.06 & -0.1 & 0.06 \\
\hline & Mo018 & Glacier de Bonne Pierre, Isère, France & 5 & -0.03 & 0.06 & -0.04 & 0.11 \\
\hline & Mo019 & Glacier de Bonne Pierre, Isère, France & 6 & 0.54 & 0.02 & 0.79 & 0.04 \\
\hline & Mo020 & Glacier de Bonne Pierre, Isère, France & 5 & -0.31 & 0.09 & -0.45 & 0.08 \\
\hline & Mo021 & Ravin de la Ruine, Isère, France & 5 & -0.08 & 0.06 & -0.11 & 0.06 \\
\hline & Mo022 & Ravin de la Ruine, Isère, France & 8 & 0.27 & 0.07 & 0.39 & 0.1 \\
\hline
\end{tabular}




\begin{tabular}{|c|c|c|c|c|c|c|c|}
\hline & Mo023 & Ravin de la Ruine, Isère, France & 7 & 0.77 & 0.04 & 1.14 & 0.03 \\
\hline & Mo024 & Tête du Rouget, Isère, France & 4 & -0.13 & 0.05 & -0.2 & 0.09 \\
\hline & Mo037 & Baltschiedertal, Switzerland & 9 & 0.2 & 0.09 & 0.3 & 0.15 \\
\hline & Mo038 & Baltschiedertal, Switzerland & 6 & 0.28 & 0.05 & 0.43 & 0.08 \\
\hline & Mo060 & Stilluptal, Zillertal, Austria & 6 & 0.16 & 0.06 & 0.26 & 0.1 \\
\hline$\overline{\mathrm{IOCG}}$ & Mo091 & Lala, China & 8 & 0.21 & 0.08 & 0.3 & 0.12 \\
\hline & Mo003 & Spain & 6 & 0.33 & 0.07 & 0.48 & 0.1 \\
\hline & Mo005 & Morocco & 6 & -0.05 & 0.03 & -0.08 & 0.05 \\
\hline & Mo006 & Québec, Canada & 6 & -0.31 & 0.07 & -0.46 & 0.08 \\
\hline Unknown origin & Mo044 & Cameroon & 8 & 0.62 & 0.07 & 0.91 & 0.09 \\
\hline & Mo068 & Borralha, Portugal & 7 & 0.09 & 0.09 & 0.13 & 0.15 \\
\hline & Mo092 & Sunderbyn, Luleå area, Sweden & 10 & 0.31 & 0.06 & 0.47 & 0.08 \\
\hline & Mo093 & Sunderbyn, Luleå area, Sweden & 10 & 0.6 & 0.05 & 0.89 & 0.06 \\
\hline
\end{tabular}


Highlights

- $\delta^{98} \mathrm{Mo}_{\text {NIST }}$ of 365 molybdenites from different geological contexts have been used to build a data base.

- Distribution of all data is close to a Gaussian one.

- Temperature of crystallization could explain $\delta^{98}$ Mo variations depending of the occurrence types.

- Variations at occurrence scale have been observed. 